\author{
V. Kalachova ${ }^{1}$, Salman Rashid Owaid ${ }^{2}$, O. Misyura ${ }^{1}$, V. Tretiak ${ }^{1}$, L. Safoshkina ${ }^{3}$, R. Gonchar ${ }^{3}$ \\ ${ }^{1}$ Ivan Kozhedub Kharkiv National Air Force University, Kharkiv \\ ${ }^{2}$ Al Maaref University College, Iraq \\ ${ }^{3}$ National Academy of the National Guard of Ukraine, Kharkiv
}

\title{
THE WAYS TO ORGANIZE OF DISTANCE LEARNING IN HIGHER MILITARY EDUCATIONAL INSTITUTIONS OF UKRAINE AND THE WORLD DURING OVERCOME OF THE CORONAVIRUS INFECTION PANDEMIC COVID-19
}

The global informatization of modern society, development of telecommunication, communicular and information technologies - on the one hand and the powerful challenges to all humanity in the form of epidemics (coronavirus infection COVID-19, bird flu, various forms of pneumatic and hepatitis), natural and man-made disasters, military and political conflicts, wars - from the second, determine significant changes in priority forms of educational process, and distance learning (DL), in these conditions, becomes the only possible option for providing quality educational services with minimal financial expenses for its organization.

Keywords: distance learning, information and educational environment, distance learning system, information technologie, learning management system, messenger, video conference, forum; chat.

\section{Introduction}

General Problem Statement. Distance learning (DL) is one of the forms of continuous education, which is intended to realize human rights to education and obtain information. The basis of the educational process at the DL is a purposeful and controlled intense selfoperation of the user educational services, which can study in a convenient place for itself, on an individual schedule, with a set of special learning tools and an agreement with the facility with a teacher by phone, ordinary or e-mail.

DL is a complex of educational services (educational material, technology, advice, knowledge check, etc.), which are provided by a wide range of population in the country and abroad with the help of a specialized information educational environment based on means of exchange of educational information at a distance (satellite television, mobile phone, computer communication, etc.) and at the heart of these services lies a methodology targeting individual (independent of place and time) of the work of customers with, specially structured, educational material, with varying degrees of communication with remote by experts, teachers and other students.

Information and educational environment (IEE) DL is a system-organized set of data transmission, information resources, interaction protocols, hardware and software and organizational and methodological support, oriented to meet the educational needs of users.

The concept of a distance learning system (DLS) is closely linked to the concept of the DL and represents a complex multicomponent system with the normative-legal base, organized structure, personnel, system engineering, logistical and financial support, which implements DL on the different levels of education and provides knowledge with distance educational technologies.

In connection with the crisis situation regarding the provision of full-time student's educational services in educational institutions of Ukraine, and all other countries of the world, which arose against the background of the pandemic of coronavirus infection COVID-19, the Ministry of Education and Science of Ukraine for Spring 2020 recommended of the all Higher Educational Institutions and Higher Military Educational Institutions of the country to move to the distance learning.

Analysis of the Recent Research and Publications. Analysis of recent research and publications has shown that at this time has not been a thorough and comprehensive analysis and structuring of services, platforms, software applications that are most in demand among organizers of distance learning (DL) during the pandemic of coronavirus infection COVID-19. The issue of assessing the quality of the implementation of DL (in particular, assessing the quality of the organization of electronic consultation in DLS) is crucial to determine the effectiveness and efficiency of distance learning services during quarantine in general.

The main regulatory requirements, recommendations, legislative acts, regulations governing the process of implementation, organization, implementation of DL in Ukraine are presented in $[1-5 ; 12]$. Effective solutions for distance learning during the pandemic of coronavirus infection COVID-19 from in Higher Military Educational Institutions and Higher Educational Institutions of Ukraine are described in [619; 31-37]. The main scientific achievements of 
theoretical and applied nature developed in KNAFU are given in $[20-30 ; 32]$.

Aim of the Research. Analysis and structuring of services, platforms, software applications for the organization of DL and conducting quality assessment of the organization of electronic consultation in DLS.

\section{Statement of basic materials}

The Ministry of Education and Science of Ukraine for Spring 2020 recommended that remote communications by participants of the educational process through the means of communication tools built into the learning management systems (LMS) such as MOODLE, Google Suite for Education, Microsoft Office 365 Education and etc.; e-mail; messengers (Viber, Telegram, Discord etc.); video conferences (Microsoft Teams, ZOOM, Google Meet, Skype, etc.); forums; chats, etc. In turn, wide opportunities for modern information technologies for the creation of simulation models of objects and processes (flash-animation, 3-D models, etc.), allow visualization of information and make the content of the distance course the most understandable and interesting for users [1-19; 31-37].

In this regard, the leading educational institutions of Ukraine, such as Ivan Kozhedub Kharkiv National Air Force University (KNAFU), Kharkiv National University of Radio Electronics (KNURE), National Technical University - "Kharkiv Polytechnic Institute" (NTU(KPI)) successfully use for implementation of DL during the quarantine of coronavirus infection COVID19 such LMSs as MOODLE; the free applications of Google Suite for Education (Google Meet, Google Form, Google ClassRoom, Google Drive, Google Calendar, Google Docs, Google Sheets, Google Slides, Google Mail, Google Search, YouTube); the free applications Microsoft Office 365 Education (Microsoft
Teams, Microsoft Sway, Microsoft Forms); own LMSs, so, for example, as, "Information Management System" ("CIM") and "Web-Class KhPI" in NTU(KhPI) and "Specialized informational and educational environment for distance learning "DIALOG" - in KNAFU [1-10].

In order to identify and further research common trends and innovative non-standard solutions for aspects of the organization of DL by advanced a Higher Educational Institutions (HEI) and Higher Military Educational Institutions (HMEI) during of the coronavirus infection pandemic COVID-19 consider the work of each of these universities separately.

KNURE: an exemplary example of the organization of DL during a pandemic COVID-19

Kharkiv National University of Radio Electronics (KNURE) considers quality education a priority Goal of Sustainable Development (GSD) and after the announcement of quarantine in the University on March 11, 2020, KNURE continued the educational process in quarantine. The KNURE has focused all its efforts on establishing and supporting the educational process with the help of distance learning technologies (DL) [5].

For many years, KNURE has been using the MOODLE platform (Modular Object-Oriented Dynamic Learning Environment) that has become more than relevant during quarantine (Fig. 1). The free system of distance learning - MOODLE, a modular objectoriented learning environment, also known as a learning management system (LMS), virtual learning environment (VLE), Course Management System (CMS) or simply a platform for learning that gives teachers, students and administrators a very welldeveloped set of tools for distance learning and the learning with the help of gadgets. MOODLE is the most perfect and widespread in Ukraine and in the world system of such an appointment [11].

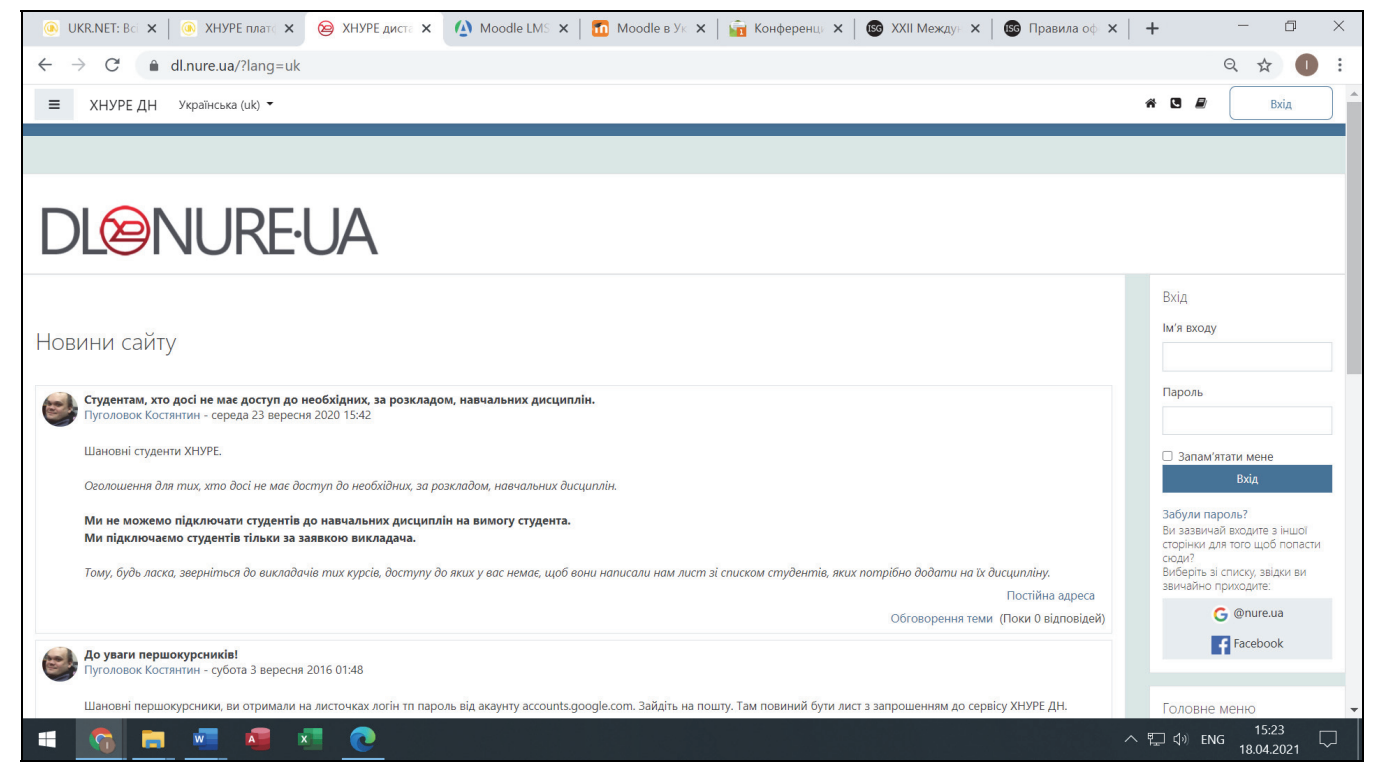

Fig. 1. The system MOODLE (DL platform "dl", deployed on the Server of the KNURE Source: developed by the authors based on the data [11]. 
At the moment, MOODLE already has nealy a few hundreds million users around the world and continues to develop pace, much faster than its competitors. In 2018 a sign event occurred. According to statistics, the use of MOODLE platform in the world has exceeded the use of all other platforms together. MOODLE translated into dozens of languages, including in Ukrainian. The system was used in 2014 - in 197, and in 2019 - in 229 countries of the world, more than 90,000 officially registered sites working on MOODLE. MOODLE is used in Europe nealy 2/3 of education institutions. In Ukraine, where the use of paid platforms is very limited, MOODLE has practically no competitors $[6 ; 11]$.

The MOODLE functionality allowed KNURE, after an unexpected announcement of quarantine, to quickly organize adaptive training in the institution. An additional feature of the platform is the ability for the teacher during the course of students in the MOODLE system of any distance course, to observe not only the success of students, but also to analyze how they are doing with competencies.

In general, the functionality of the platform can be used both for self-training and for distance learning, certification and retraining of specialists, for the organization of lifelong learning and so on.

In turn, the services from Google Suite for Education - Google ClassRoom and Google Meet, allowed KNURE to establish the educational process as quickly and efficiently as possible (Fig. 2). Google has created a distributed system of support and training of users for its services. In addition, close integration of Google services with the distance learning management system - LMS MOODLE [6; 11].

Google Suite For Education as and Microsoft Office 365 Education have a number of advantages compared to any other cloud services. Clouds of these companies are provided with educational institutions for free. This is a very important advantage, since creation and support of products of this class and quality requires significant resource developers companies. These services are created by the highest class specialists. This provides stable work, the minimum number of errors that are quickly corrected, hacking resistance, compliance with modern web standards, a correct reflection in different browsers, etc. Clouds of these companies are updated regularly $[6 ; 11 ; 13 ; 16]$.

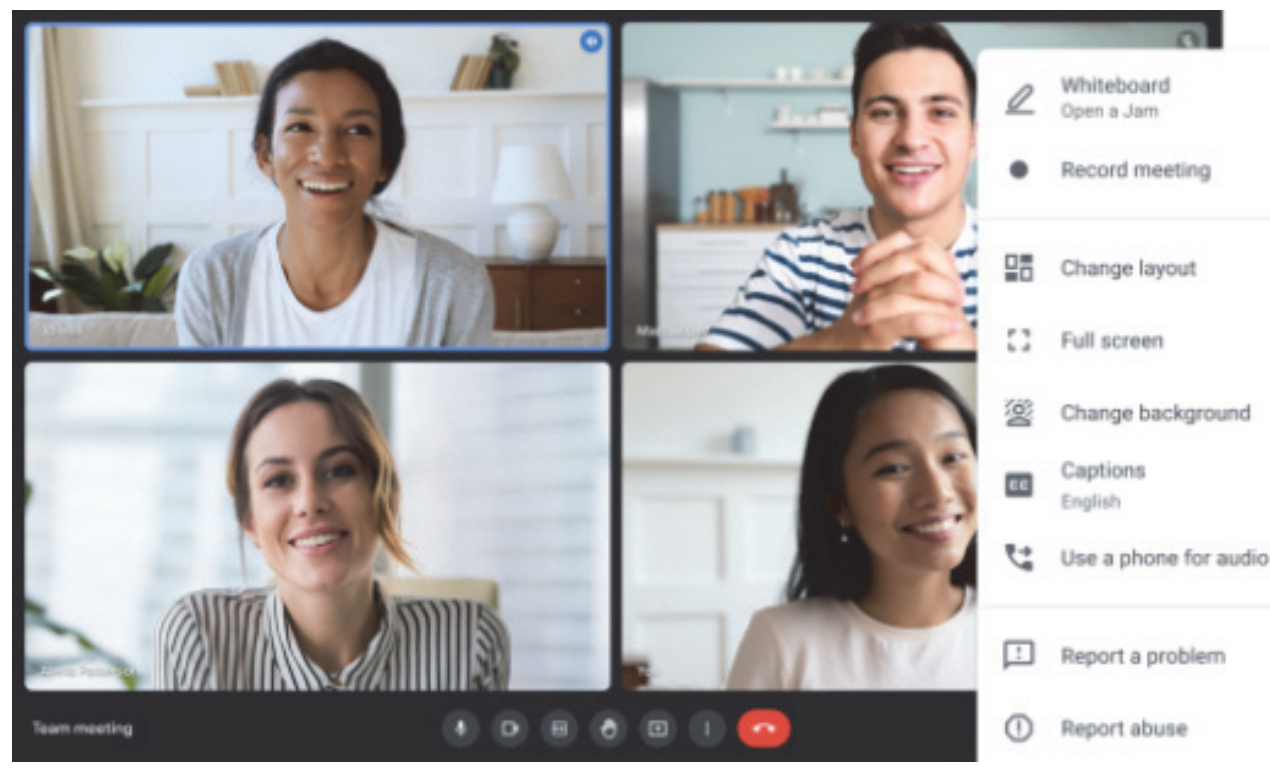

Fig. 2. The software application Google Meet from Google Suite for Education platform window Source: developed by the authors based on the data [13].

Adaptive (respective) design these software applications provides correctly displaying sites on mobile devices. Due to this, for working with resources created on the basis of cloud services of these companies students can use their own mobile phones. They are also characterized by simplicity and userfriendliness. Their interface is intuitive.

The differences between these educational packages are not very significant. They are determined by developing services to various companies and various developer teams. However, one significant difference is still taking place. It is about availability of services for individual users.

Google and Microsoft recommend for educational purposes to use educational packages Google Suite For Education or Microsoft Office 365 Education, which are provided with non-profit education institutions for free and provide a number of additional opportunities, in particular, an increase in the size of the cloud storage, full absence of advertising, etc. Connecting data packets 
is possible only by the administration of the educational institution, a separate user can not receive them. And this is shared for these software applications.

The difference between them is that Google Suite for Education is not required for use Google's cloud services to compulsory connection of Google Suite for Education package. It is enough to create a Google account, after which all Google Services will be available. Of course, there will be not privileges in the form of a larger size of a cloudy repository and a guaranteed absence of advertising, but the use of cloud services with an individual user is possible $[13 ; 16]$.

The use of cloud services which are part of Microsoft Office 365 Education, a separate teacher is impossible if the educational institution has not connected this cloud package. An exception is the Microsoft Sway service that is part of Microsoft Office 365 Education, but can be used without connecting the Microsoft Office 365 Education package.

Due to the seasonal deterioration of the epidemic situation of COVID-19 coronavirus infection in Ukraine and in the world in general, Google Suite for Education has found an opportunity to offer a full range of all available its services for free, including for users of KNURE.

The list of the most popular of them includes Google Drive, Google Calendar, Google Docs, Google Sheets, Google Slides, Google Mail, Google Search, YouTube. Full integration of services creates a unique ecosystem and a single repository of documents and files that has no restrictions. In addition to the main services, Google offers a number of equally important services that improve the quality of collaboration: Google Groups, G +, Google Hangouts, Google Contacts, Google Forms and Google Sites [13].

It should be noted that, Google Meet has become wildly popular among users for both Ukraine and the world generally during the COVID-19 coronavirus pandemic. It happened because it is very convenient to hold secure video conferences. You can join them from a special application or the actual version of any webbrowser.

During the pandemic, Google shared the general access to corporate video conferences functions and now of all Google accounts users can hold the online meetings of up to 100 participants for up to 60 minutes each.

The educational institutions can use extended functions, including meetings of up to 250 participants from inside and outside the institution, and also to broadcast of live stream for a maximum of 100,000 viewers in the domain $[6-11 ; 13]$.

KNURE also joined to the program "Coursera Coronavirus Response Initiative" and provided students and staff the free access to Coursera educational courses.

The "KNURE DL" service http://dl.nure.ua/, created on the MOODLE platform, is administered and maintained by the Center of Distance Learning Technologies https:/nure.ua/branch/tsentr-tehnologiydistantsiynogo-navchannya, which was created at the University in 2001 (Fig. 3).

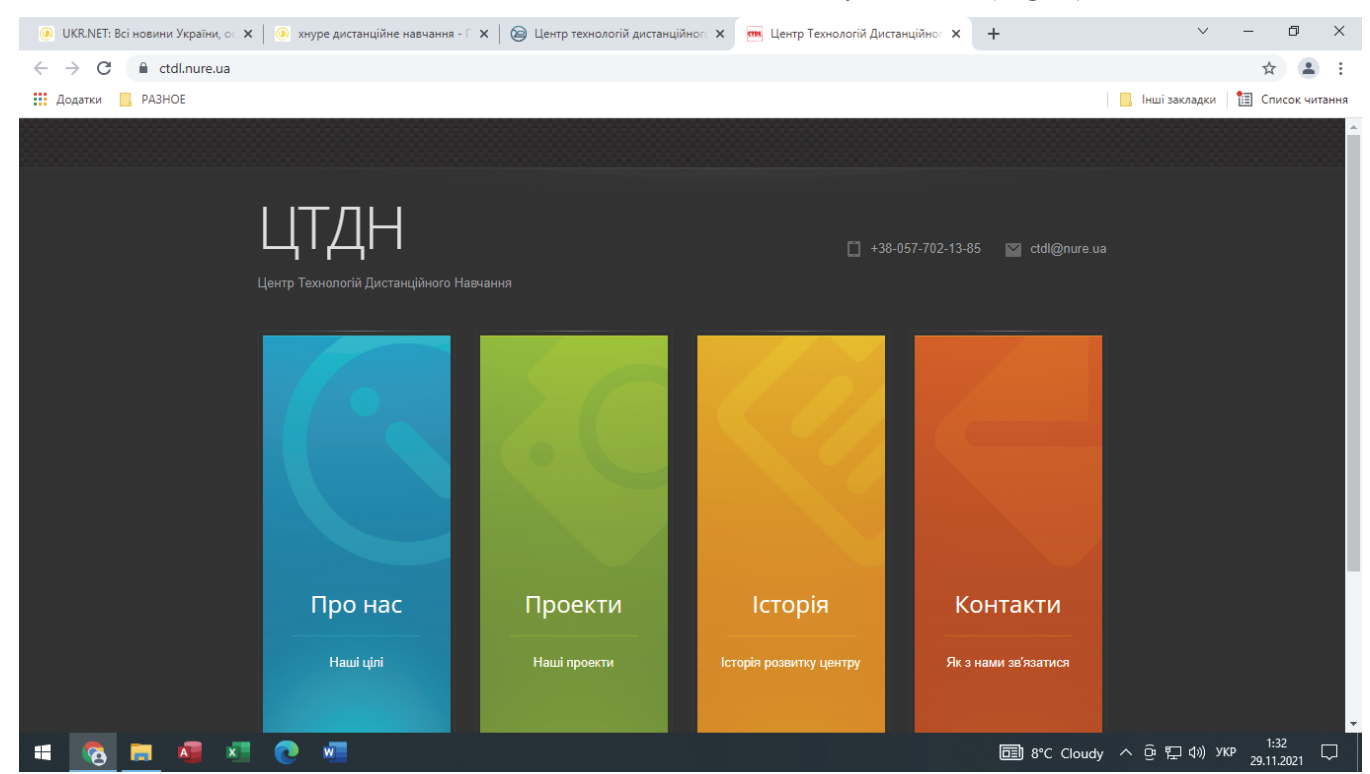

Fig. 3. The Center for Distance Learning Technologies of KNURE Source: developed by the authors based on the data [11].

To ensure the DL and set up all information services during the organization of the educational process in KNURE uses a single system of creating and maintaining accounts of users of the information ecosystem of the institution with support for e-mail addresses in the domain nure.ua for all participants (students, teachers, staff). Currently, more than 10,000 user accounts of the university are active. More than 1,300 distance learning courses have been created. About 5.5 thousand students and about 600 teachers use the "KNURE DL" service. 
Of considerable interest, both for research and for the use of the experience of KNURE in other HEIs (HMEIs) of Ukraine and the world, is the practice of KNURE on conducting laboratory classes within the implementation of DL.

Extensive capabilities of modern information technology to create simulation models of objects and processes (flash-animation, 3-D models, etc.), allow to visualize information and make the content of the distance course as clear as possible to the user. Unique for the educational process in quarantine was a version of educational video content, created at the Department of Biomedical Engineering (BME) KNURE, which is designed for laboratory work in technical disciplines, which uses complex hardware (Fig. 4, a).

This content is based on the use of modern video technology with the effect of presence, which allows the user during such a remote lesson to face the maximum possible level of clarity and reality when working on complex equipment with macro and micro review, demonstration of different devices separately from each other and all together.

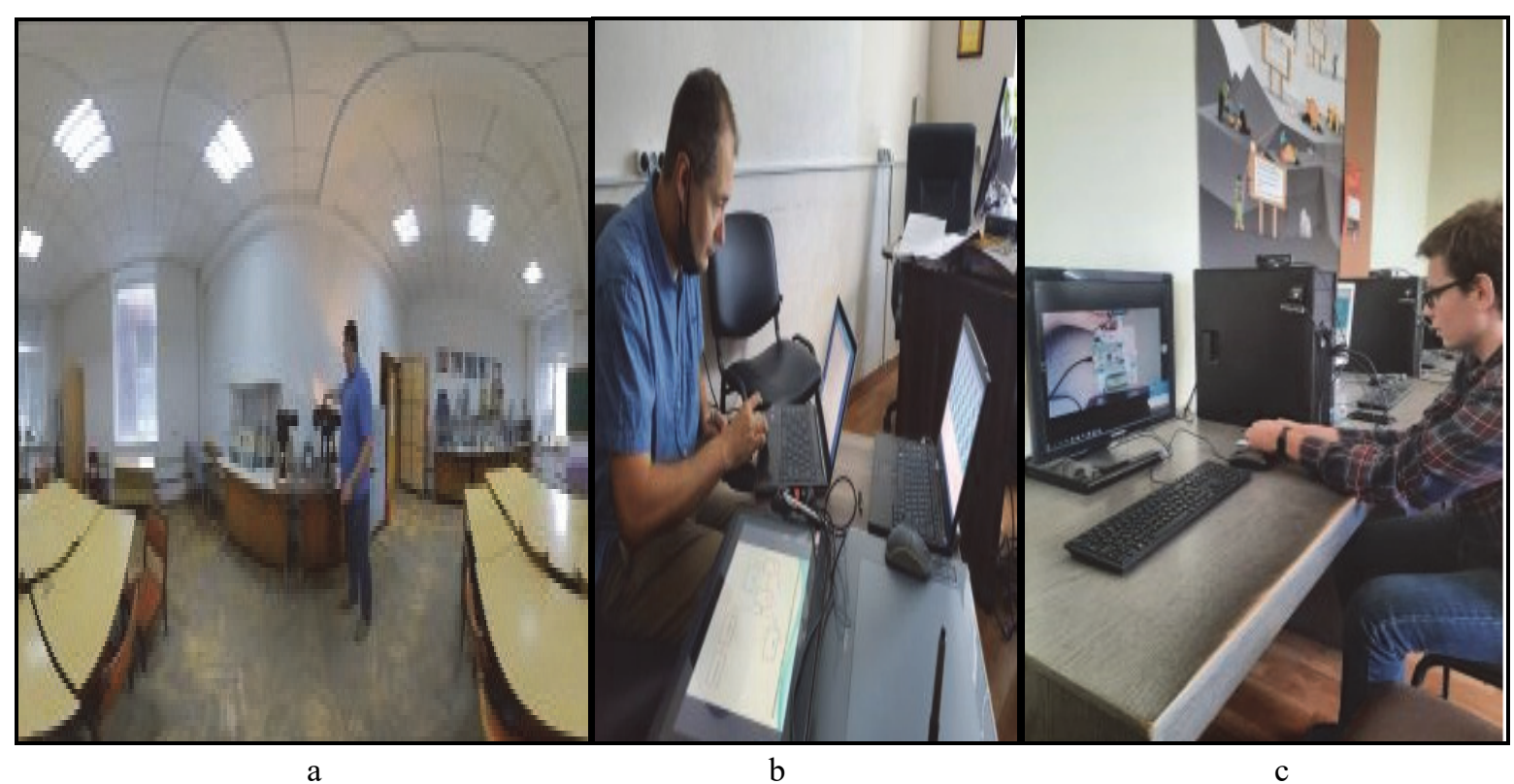

Fig. 4. Examples of application of innovative educational content, methods, equipment for the implementation

of DL from KNURE: a - content based on the use of modern video technologies with the effect of presence

(panoramic video); $b$ - graphics tablets and interactive screens for organizing the dynamic mode during the on-line lesson; $\mathrm{c}$ - laboratories with support for remote access to equipment

Source: developed by the authors based on the data [11].

The panoramic video that underlies this content allows the distance learner to have a field of vision, not the cameraman who shoots the classroom or computer class, the classroom or the lab.

Content based on the use of modern video technology with the effect of presence is a combination of the latest technologies and explanations in chalk on the blackboard. This is a real effect of presence in the classroom, where there is a teacher who demonstrates and explains the principles of equipment, and students at their workplaces in cyberspace.

By the way, thanks to the creation of BMI content with the effect of presence for the implementation of DL during quarantine in the country in connection with the pandemic of coronavirus infection COVID-19, KNURE was able to get a worthy place in the ranking of universities - Times Higher Education University Impact Rankings.

Also, teachers of the Department of BME KNURE conduct classes remotely using the latest teaching aids, such as graphics tablets and interactive screens. This allows teachers to perform transformations of mathematical expressions and write fragments of program code when conducting remote classes in dynamic mode while demonstrating the screen. This, in fact, combines the approaches of teaching in the blackboard and the presentation of material in the form of a presentation and significantly expands the methodological possibilities of conducting classes remotely during the demonstration of the screen (Fig. 4, b).

From the beginning of the autumn semester of 2020-2021 academic year, the Department of Microprocessor Technologies and Systems (MTS) has two laboratories with remote access to equipment (online laboratory), where students can create a project in real time and test its viability outside laboratories. Laboratory classes are conducted using the Moodle platform (dl.nure.ua), video conferencing in Google Meet and remote access to PCs and laboratory layouts. (Fig. 4, c).

Students and faculty use the TeamViewer remote software package to remotely access PCs in labs. 
Adjustment of laboratory equipment and support during laboratory work is provided by teaching and support staff of the department.

For laboratory work, the latest equipment is used, which has the ability to connect to a PC. Laboratory models and oscilloscopes are completely controlled by a personal computer. And with the help of the camera the work of the laboratory model is broadcast on the monitor. This allows you to upload projects to laboratory layouts remotely and view the results of their work on a computer monitor using specialized software.

This approach to laboratory work on microcontroller design allows students to gain hardware skills, practical microcontroller programming skills, and provides students with additional skills for remote hardware operation.

KNURE's experience in conducting online exams for specialists in the organization and implementation of information technology in the educational process of higher education is no less intellectually valuable than the experience of this higher education institution in conducting online laboratory classes [11-13].

The algorithm for the exam is as follows. The module "Exam" with the section "Tasks" is added to the module of this course in the service "KNURE DL" http://dl.nure.ua/, which was created on the MOODLE platform. This section provides a folder for each student, in which the student puts his answer to the exam ticket. At the beginning of the exam, the teacher and students meet for a video conference at Google Meet.

To confirm participation in the exam, each student sends from his e-mail address on the domain nure.ua a blank letter to the teacher, and in response receives a pdf file with the exam ticket. During the time allotted for the exam, students write answers to the questions of their tickets. Each student photographs his handwritten answer, forms a pdf file and sends it to the course page, placing it in the topic "Exam", section "Tasks", in a folder with his name.

The time allotted for checking the works (usually several hours) the teacher checks the answers. Then, all participants of the exam (students and teacher(s)) gather again for a video conference, where each student is voiced by the teacher. The assessment depends not only on how well the answers to the questions of the examination ticket are written, but also on the results of the work during the semester, the laboratory and practical tasks performed.

In parallel, the Educational and Research Center for Distance Learning (NSCPF) clearly and deliberately performs work on the formation and timely provision of teachers and students of the group participating in the exam accompanying this exam electronic documentation: electronic information and instructions for its completion are sent in advance; e-mail addresses of students on the nure.ua domain are also sent in advance.
The real SENSATION of 2020 for distance education in Ukraine and the world in general was the event held by the Kharkiv National University of Radio Electronics in the summer during the exacerbation of the pandemic coronavirus infection COVID-19 - for the first time since its existence, the university defended bachelor's and master's theses COMPLETELY, from start to finish, remotely, using the service for video conferencing from Google Suite for Education - Google Meet (Fig. 3) [11-13].

The defense of bachelor's and master's theses in KNURE has an algorithm that fully complies with the "Recommendations for the organization of current, semester control and certification of students using distance technology" provided by the Ministry of Education and Science of Ukraine on May 14, 2020, and has the following components.

Certification of persons at the first (bachelor's) or second (master's) levels of higher education in the form of defense of qualifying work using distance learning technologies is carried out in synchronous mode (videoconference). At the same time, digital fixation (video recording, audio recording, photo fixation, etc.) of the attestation process is obtained in the form of defense of qualification work.

At the time of defending the qualifying work, the electronic copy of the work with the electronic digital signature of the student must be in the examination commission (it must be sent in advance by the student by e-mail). The examination commission verifies the digital signature.

The decision of the examination commission on the result of the defense of the qualification work takes effect after the examination commission receives a copy of the work and after the completion of the accompanying documents. The digital record of the process of protection of qualification works is kept in the educational institution for at least one year.

The secretaries of the examination commissions send the minutes of the meetings of the examination commissions and reviews (their photocopies) to the deans' offices by e-mail no later than the next working day after the scheduled defense of qualifying works.

As an exception to the conditions of strict quarantine, the educational institution gives the secretary of the examination commission the right to collect signatures on paper copies of all documents (reviews, reviews, protocols) after quarantine and provide completed documents on the results of protection to the deans and qualification works to the archives.

Now KNURE is gradually implementing the recommendation of the Ministry of Education and Science of Ukraine on the transition from storing paper copies of qualifying and term papers in the archives to creating repositories of electronic copies and copies certified by the necessary electronic digital signatures. 
NTU (KPI): educational process in quarantine

Two educational shells are actively used in the educational process of NTU (KPI) - "KPI Web Class" (Fig. 5) and "Information Management System"
('CIM") (Fig. 6), developed and manufactured by the university specialists, as well as the freely distributed MOODLE shell [6-10; 14].

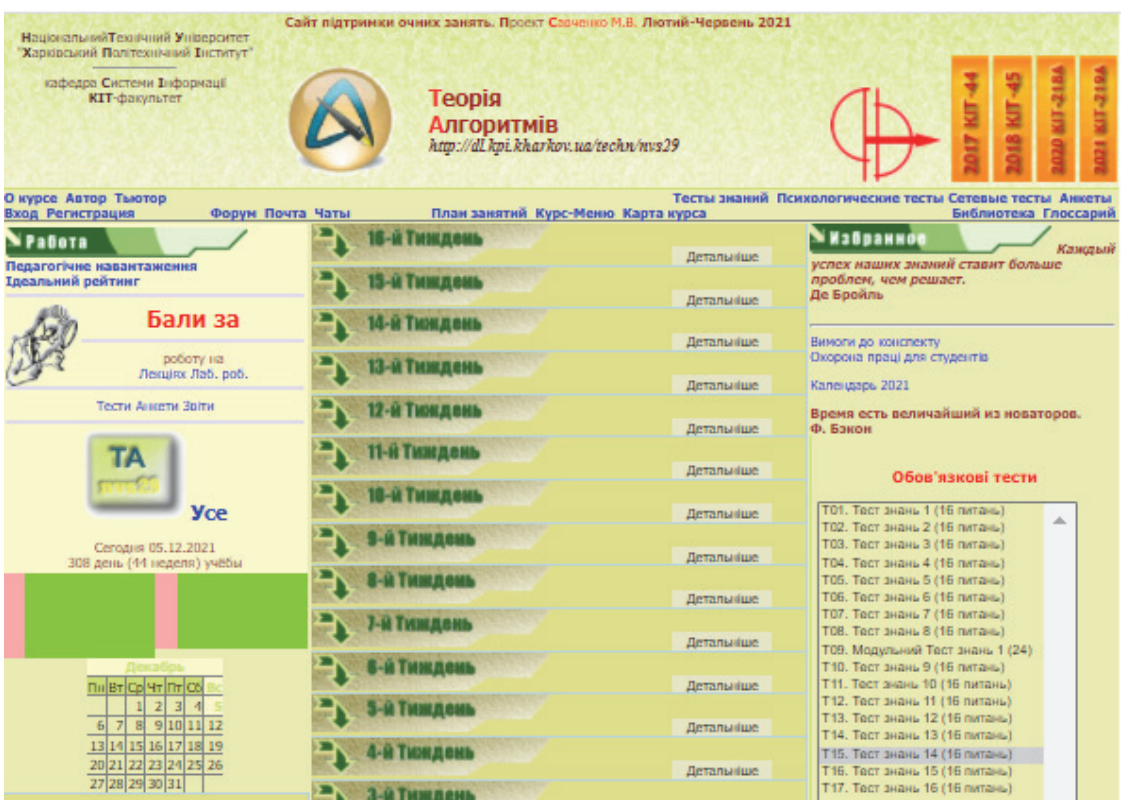

Fig. 5. Starting page of the educational shell "KPI Web Class" NTU(KPI) Source: developed by the authors based on the data [14].

The Moodle shell is used mainly as an experimental base for scientific and methodological work and for the implementation of corporate projects in the field of e-learning. Moodle has more than 90 distance learning courses.

The "KPI Web Class" training shell has been operating since 2001 . With the help of this shell, more than 200 distance learning courses have been developed.

From the point of view of the use of information technologies the problem of distance learning organization in higher education institutions is also interesting and NTU(KPI) training shell - "Information
Management

System"

("CIM", http://cde.kpi.kharkov.ua) which has been developed by scientists of this educational institution and functioning since 2004.

It is a learning management system (LMS) which includes more than 250 distance learning courses and its most basic parameters meet the requirements of the international standard of SCORM. "CIM" is a software complex that provides the work of teachers and students in any distance learning format - consulting, resource and instruction.

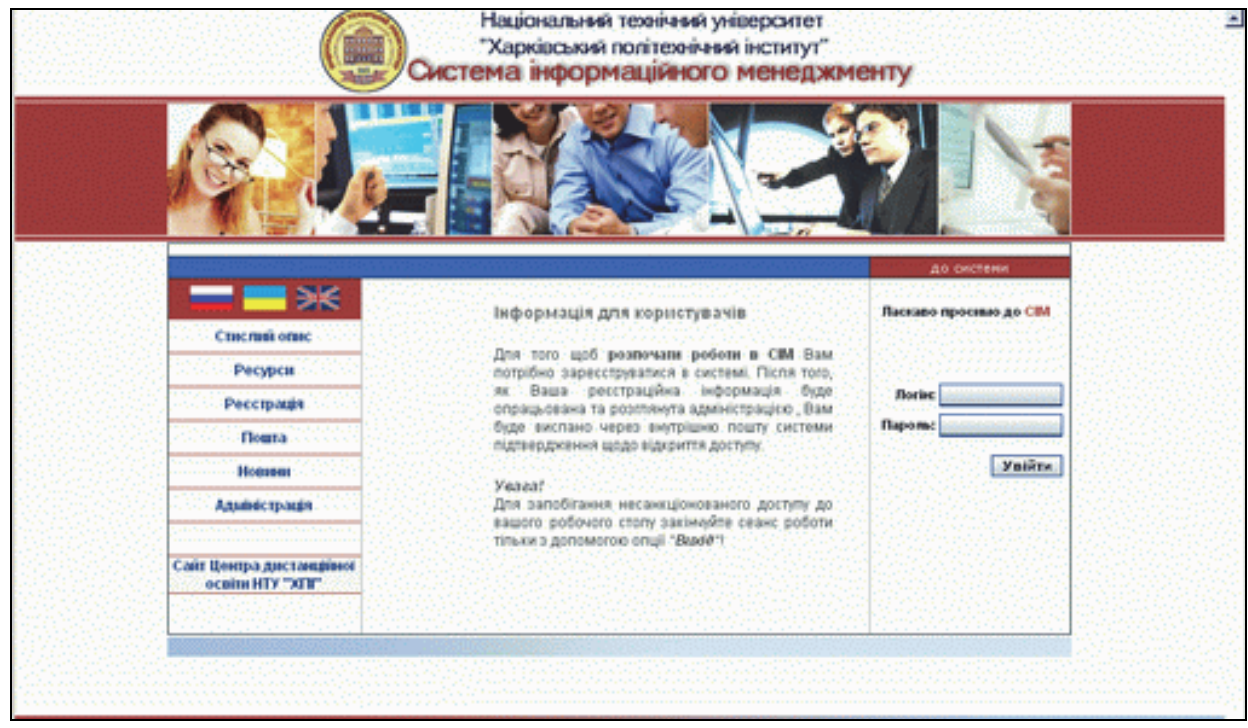

Fig. 6. Starting page of the educational shell "Information Management System" ("CIM") NTU(KPI)

Source: developed by the authors based on the data [14]. 
The methodological principle of building "CIM" is the distribution of responsibilities among the participants of the educational process. This approach give an opportunity to create a maximum user-friendly computer desktop interface for teachers, students and other users, that do not require special programming knowledge - enough only elementary skills of working with Internet browsers. An important feature of "CIM" is a developed system of administration of the educational process, which actively uses a rating system of evaluations and modular control and provides a detailed tracking of educational activities of teachers and students.

In the "CIM" includes a developed system of archiving of personal cases of users and other educational documents with a search for their attributes (S.N.P., the year of entry, educational group, specialty). "CIM" contains user registration and authorization modules, an internal mail server, a constructor of courses and tests, a built-in library of educational resources with the ability to find a resource based on its main features (author, place of publications, keywords) and the formation of a personal user library.

Free software applications from Google, such as: Google Forms, Google Classroom, YouTube, have found their circle of users-fans and among the teaching staff of the departments of NTU (KPI).

Viber and Telegram messengers are the most popular for use by teachers in the distance learning process at NTU (KPI).

Microsoft online forms from Microsoft Office 365 Education are mostly used for online testing of students in the educational institution. Configuring the service allows you to open the test only for a specified period of time and $\log$ in to a pre-created account.

The Educational Institution also actively uses the ZOOM (Fig. 7), Google Meet, Skype services to conduct on-line meetings and video conferences.

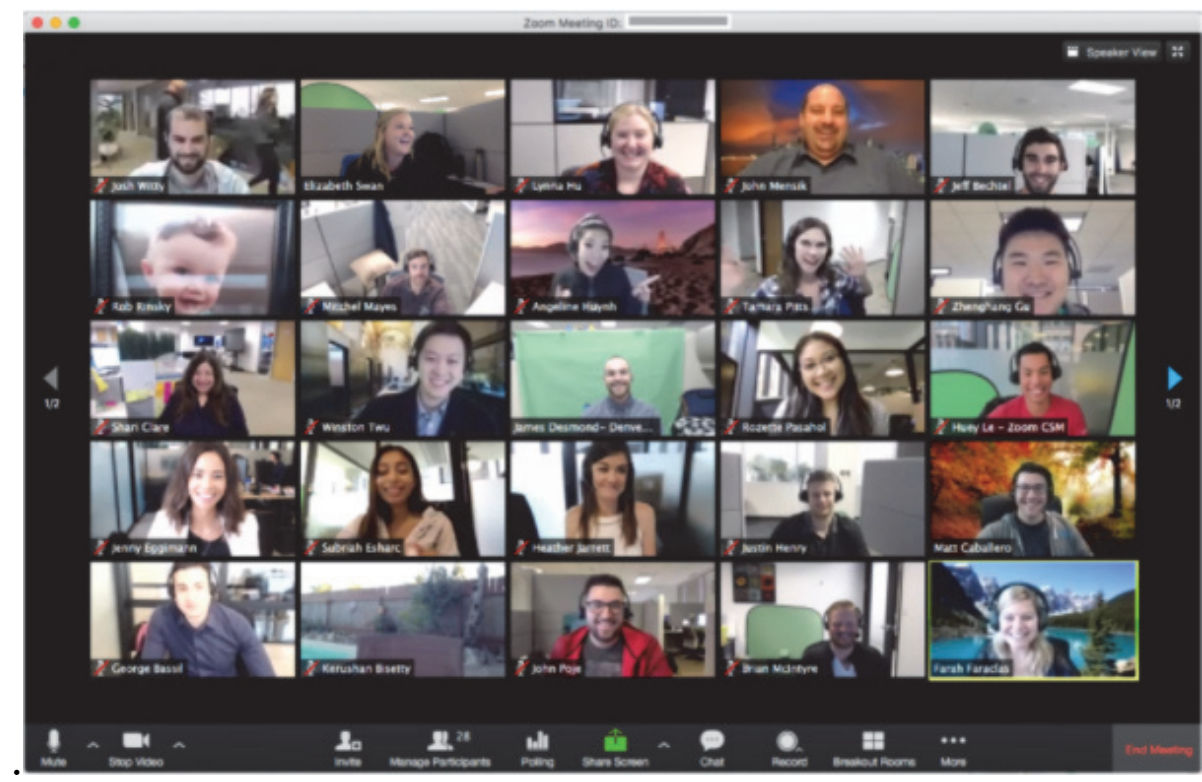

Fig. 7. The window of software application Zoom

Source: developed by the authors based on the data [15].

The Zoom service is used to maintain business relationships, conduct online meetings and study in educational institutions. You can access the program from a computer, a tablet and a phone [15].

Anyone who has created an ZOOM account can arrange an meeting. A free account allows to hold of video conference for lasting 40 minutes, but the service has removed this restriction during the coronavirus pandemic.

Anyone user with a link or conference ID can join the video conference. The event can be planned in advance and also can make a recurring link, that is for a permanent lesson at a certain time you can make the same link to enter.

There are many software applications and platforms for video conferencing at that time. They are all similar but have characteristic differences.

The main advantages of software application Zoom that make it so popular among users, compared to other software applications for video conferencing and on-line meetings are: excellent communication; video and audio communication exists with each conference participant; screen demonstration is possible with sound; an interactive whiteboard is built into the platform, which can be shown to all participants of the videoconference; you can record a video conference; the possibility of granting the rights to administer the conference to the co-organizer.

But the Zoom service has many worthy competitors in terms of the functionality of the application for online meetings and video conferencing, such as Microsoft Teams (Fig. 8) [16]. 


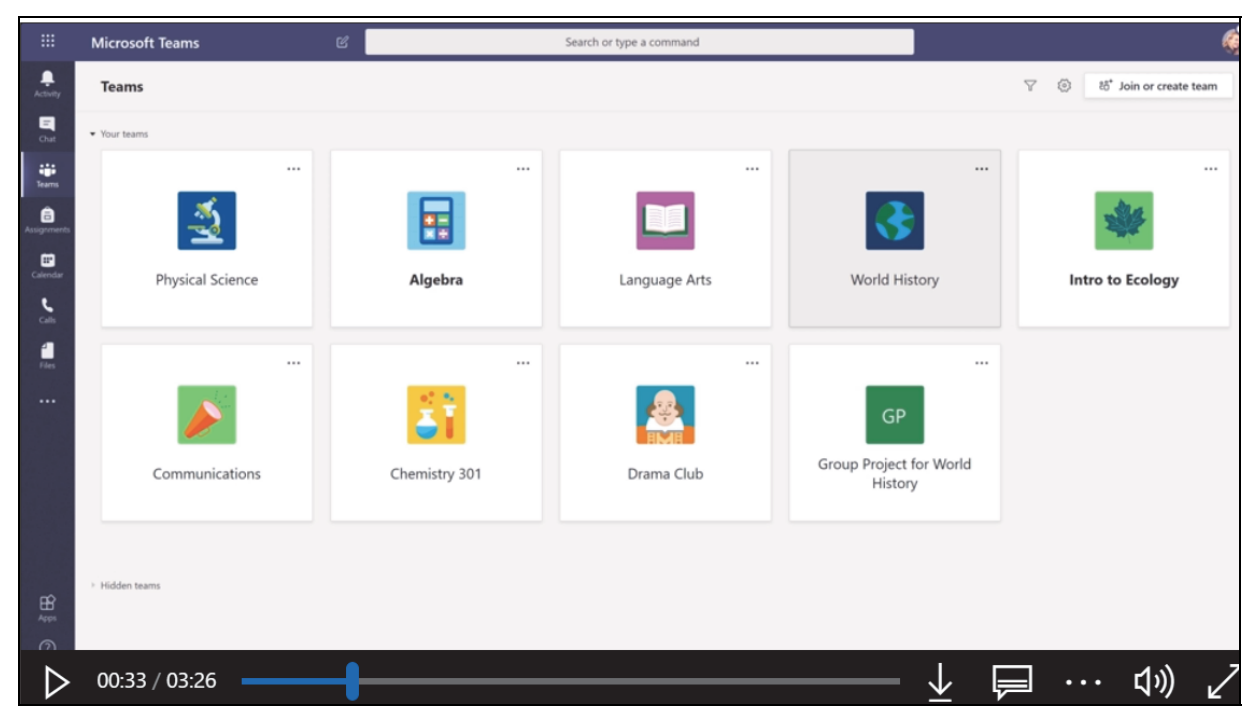

Fig. 8. The window of software application Microsoft Teams of Microsoft Office 365 Education platform Source: developed by the authors based on the data [16].

KNAFU: effective innovative solutions for the implementation of DL in HMEI of Ukraine and the world

On the way to solving the problem of overcoming the educational crisis that arose in the world in connection with the unexpected flash of the coronavirus infection pandemic Covid-19 in 2020 for Ukraine that also eighth year in a row is in a state of resistance aggression of Russian occupation troops against Ukraine, the issue of providing quality education to military specialists by the Higher Military Educational Institutions of Ukraine, takes fateful nature, in terms of victory over the enemy. In these conditions, DL, which combines the best methods of innovative learning with the super modern information technology, becomes the only possible option for providing quality educational services [17-21].

Systems of distance learning (DLS) of the Supreme military educational institutions of the Armed Forces of Ukraine are part of the education system of Ukraine, in which the DL is based on the didactic, methodological, organizational and informational principles and, taking into account the confidential nature of the information content of most educational disciplines, uses for communication of the Intranet type network, which have functionality the Internet is for internal use only [18]

Kharkiv National University of the Air Force Ivan Kozhedub (KNAFU) is conducting research on improving the effectiveness of training and assessment of the its personnel, based on the use of innovative information technologies, organization and implementation of distance learning (DL) [17-21].

At present, the main information technologies for automation of learning and realization of its distance form which were developed and partly implemented in KNAFU with the purpose of effective specialists training increase are: the informational and educational environment "DIALOG"; the universal system for the development and conducting of computer tests; the complex of designing the academic schedule "CASCAD". In addition, the learning process successfully uses the distance learning system with the open source code - MOODLE and the platform of Discord is used establishment as a ground for realization of international scientific conferences in their controlled from distance version [18-21].

The universal system for the development and conducting of computer tests has been developed and implemented (Fig. 9) [22-26]. The developed software application allows to solve the following tasks: locally, on separate PCs, to develop computer tests and conduct testing and self-control of those who study; choose the types of answers to questions (with one correct answer, with a few correct answers, with a response in the form of a record); divide the questions by category and type of answers and give the corresponding number of points for the correct answer; to randomly distribute questions by categories; use as a matter of a variety of document fragments (graphic, formulas, etc.) from other programs (MS Word, MS Excel, etc.); enter type of time limit and time limit; to pass the test and return to the questions; at the end of the test, analyze the responses [22-26].

The developed program complex of the automated system of designing the lessons schedule is deployed at the work places of the educational departments of the faculties and the department of the university and is successfully used during the planning of the educational process at the university (Fig. 10).

The main advantages of the software complex "CASCAD" are: it is an unique software product, created at the university, which fully corresponds to the content of all stages of the planning of training sessions for the semester; automatic control of the formation 
lessons schedule according to the defined criterias of the quality of the lessons planning; automatic fixing of all user actions to change data; automated formation of reporting (statistical) documents for the planned learning process [27-30].

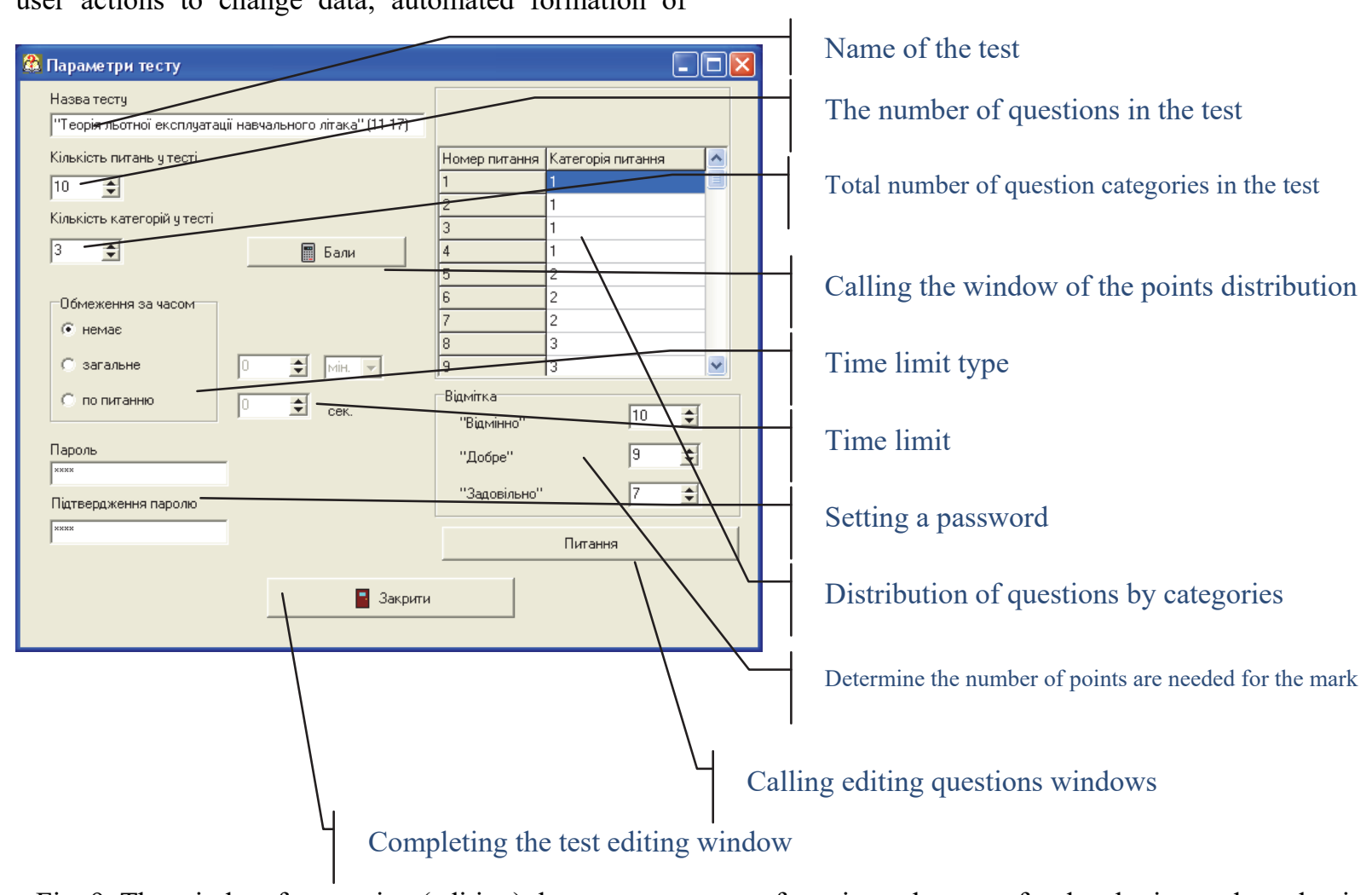

Fig. 9. The window for creating (editing) the test parameters of a universal system for developing and conducting computer tests

Source: developed by the authors based on the data [17].

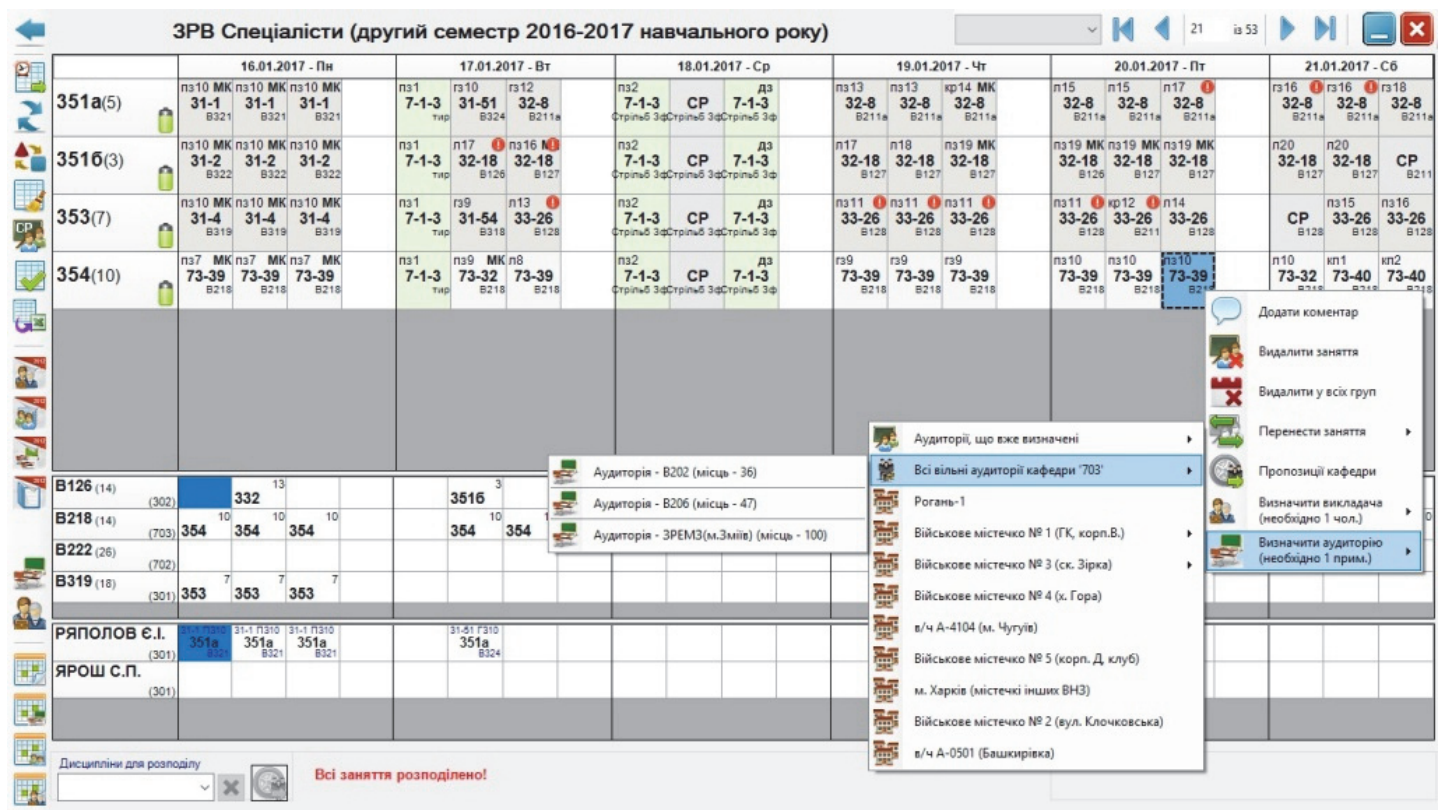

Fig. 10. User interface program complex of automated system of designing the lessons schedule "CASCAD" Source: developed by the authors based on the data [17].

Perspective directions of improvement of the program complex "CASCAD" are: expansion of the created software complex functionality due to the development of new modules: the account of participants in the educational process; account of the success and ranking of university cadets (students); expansion of the list of accounting documents; development of procedures for the automatic formation 
of the basic optimized lessons schedule for the semester, taking into account the given restrictions (using genetic algorithms); creation of software modules of management and operative adjustment of curricula directly during the educational process; creation of an complex system of automated control of the Higher Military Educational Institution (based on the integrated components: personnel, logistics, planning and management of the educational process, financial support, etc.) [27-30].

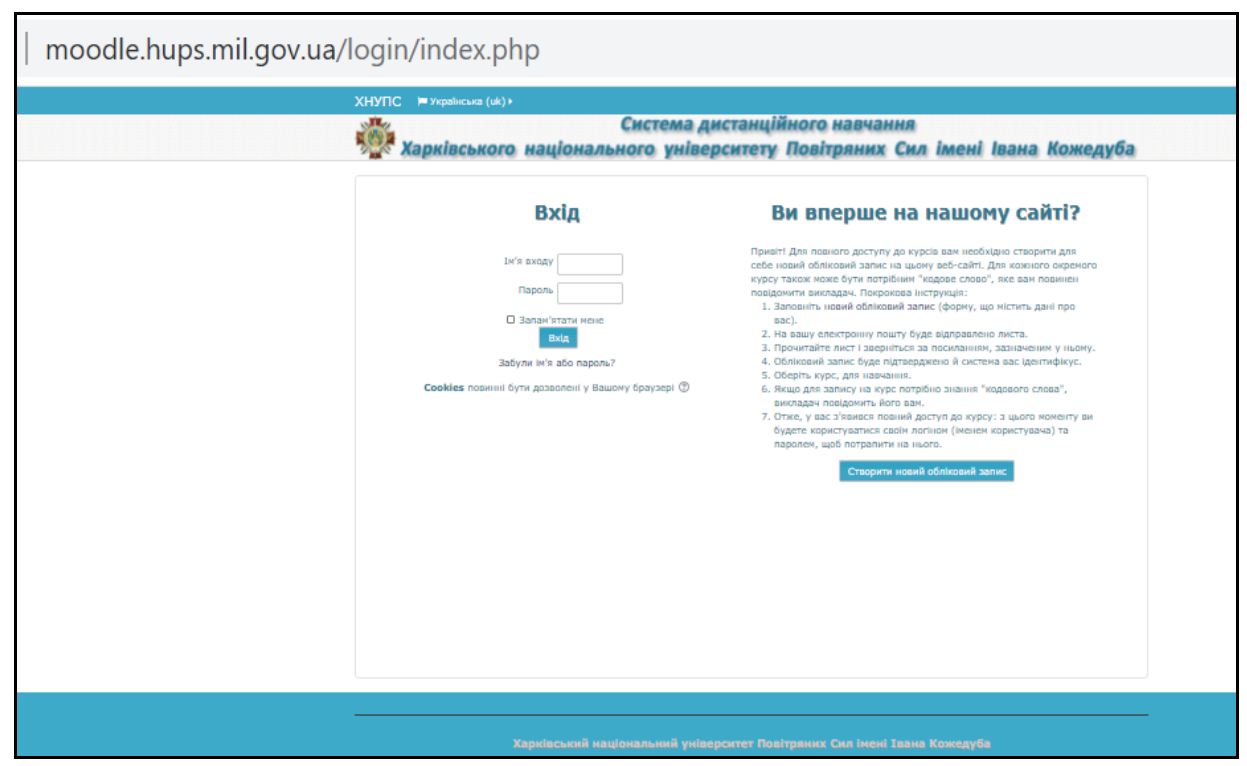

Fig. 11. The system MOODLE, deployed on the Server of the KNAFU

Source: developed by the authors based on the data [17]

For remote conferences, KNAFU periodically uses the capabilities of the Descord messenger (Fig. 12).

The messenger Discord is a program that allows community to communicate quickly with text or voice messages. The application has developed for online games in which players need to be promptly exchanged views and strategies. The advantage of Discord is that it organizes all the capabilities for communication in one place [31].

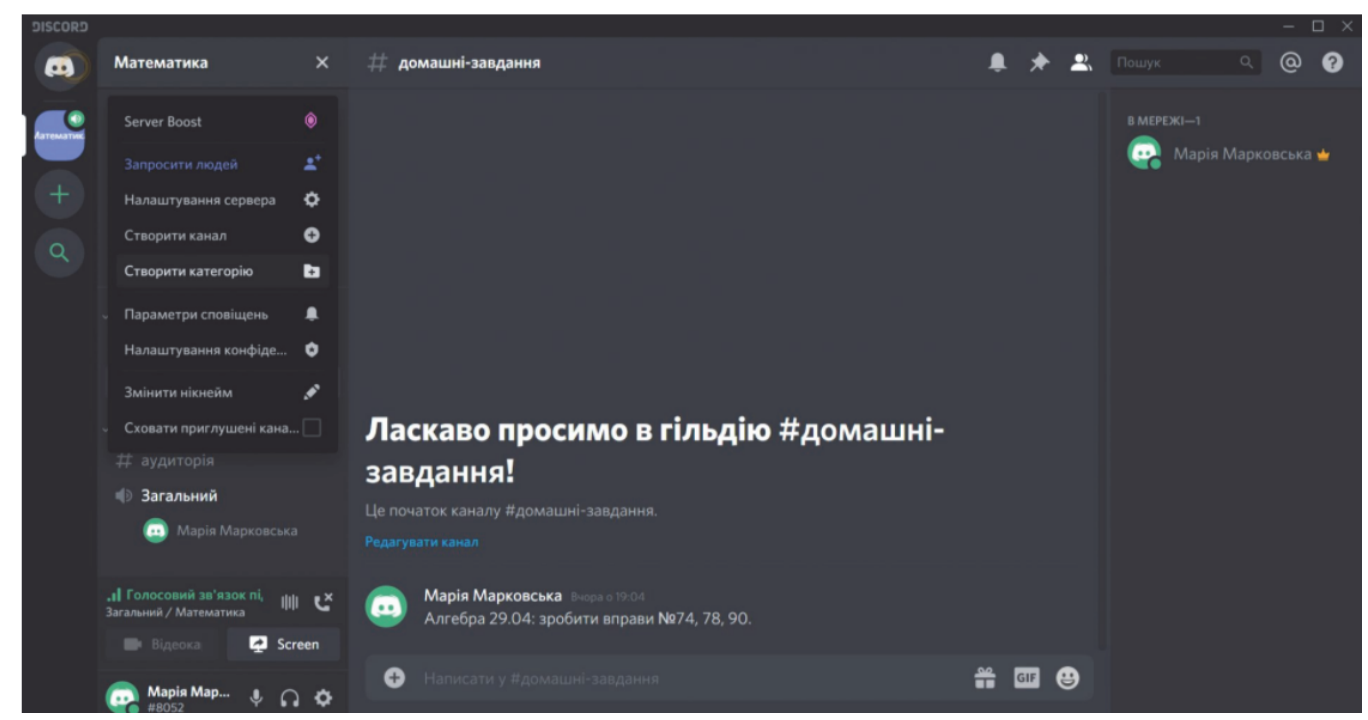

Fig. 12. Example of software environment Discord window deployed on a KNAFU University server during a distance conference

Source: developed by the authors based on the data [17].

Discord, as well as each software product, has a number of advantages and disadvantages. Discord video is possible only in screen demonstration format. If you need to see students, it's better to use ZOOM. You can not record broadcasts in the program. Discord has no time limit for video broadcasting. There may be an 
unlimited number of participants in chats. Each message can be added to emotions, thus a teacher and other participants can see that others think about one or another message. So you can and expose scores [31].

By the way, on April 14-15, 2021, the Discord platform was used to realize it in a distance format to hold the 17th International Scientific Conference "Newest Technologies - for Airspace Protection" in KNAFU. Software application Discord allowed community to communicate quickly with text and voice messages. According to the results of the conference, it turned out that the platform is a well-adapted to hold of video conferences with a large number of participants (Fig. 12).

As a result of conducting research on increasing the effectiveness of combat training through the use of distance learning technologies, the informational and educational environment "DIALOG" has been developed by KNAFU scientists in 2008, and is DLS which allows: to plan training by distributing subjects by type of training; to study as a group according to the subjects for which they are studying; organize classes in accordance with the requirements of the orders of the Ministry of Defense Ukraine regarding the training of military specialists; to carry out automated control of testing of those who learn with automatic fixing of time and results of passing tests; control the process of learning by the average score for the group, the course through the system of statistical data generation (Fig. 13) [32].
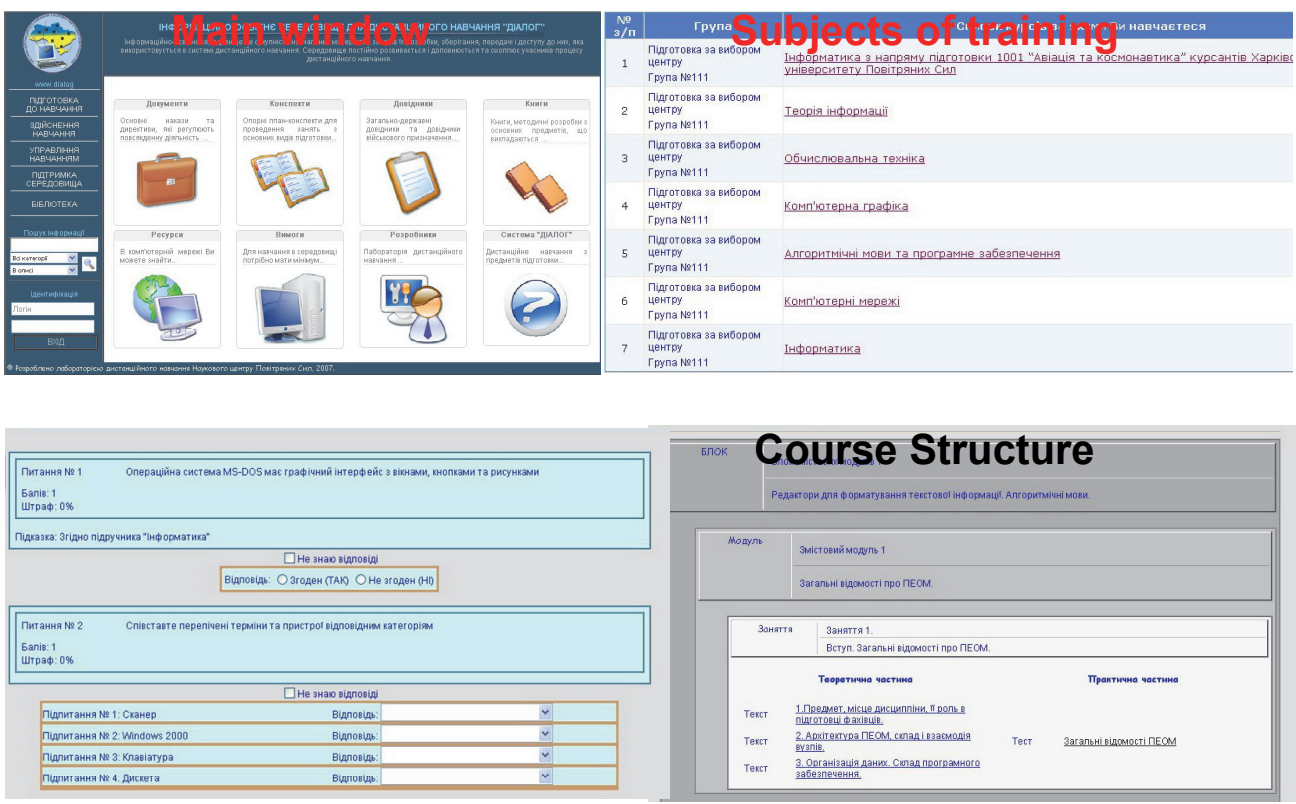

Fig. 13. The specialized informational and educational environment "DIALOG" for distance learning Source: developed by the authors based on the data [17].

The success of distance learning in DLS depends on the organization of educational material. The distance course (DC) is designed for distance learning.

Any DC of IEE "DIALOG" consists of the following components - types of classes: lectures; practical, group, individual lessons; individual tasks; independent work, seminars; consultations; modular control of knowledge [32-34].

Of particular interest for the research is

Algorithm for conducting electronic consultation in IEE “DIALOG"

Consultation - a type of training session in which the student receives from the teacher answers to specific questions or explanations of certain theoretical positions or aspects of their practical application [33].

Electronic consultation is one of the types of training sessions and is a form of guidance for independent work of students and provide them with assistance in mastering the training material. There is a purposeful exchange of information between the teacher conducting the consultation and the students. When studying in IEE, it is recommended to hold regular consultations so that students have a system of support in learning information, and the teacher monitors the progress of the learning process [34].

Electronic consultations can be classified by type of connection, as those that take place in real time (online) and in a certain time (off-line).

In the process of conducting such a consultation, the teacher can personally address in writing to each student, or to all at once, using the technological means of IEE.

Conducting electronic consultations can be divided into three stages: preparatory, basic, final.

At the preparatory stage:

a) participants in the educational process receive identification details;

b) the teacher draws up a consultation schedule, 
determines its form (group or individual), draws up a consultation plan, which reflects:

1) the topic of the consultation;

2) the main issues of the consultation topic;

3) the key points of the training session are highlighted;

4) a list of literature recommended for the lesson;

c) the teacher prepares "sample" answers to expected typical questions and organizational questions. It is necessary to have all the training and reference material on the topic of the lesson, which can be useful in formulating answers to students' questions;

d) the assistant-consultant checks the availability and readiness of the equipment for work, puts all the prepared materials in the IEE (on the site);

e) the student gets acquainted with the teaching materials presented in the IEE [35].

At the main stage, the teacher conducts a consultation in the learning environment.

Experimental work on distance learning has shown the feasibility of introducing a limit on the number of questions asked to students (in the general case, it is enough to limit 3-5 questions on each topic of the curriculum). Otherwise, as practice has shown, the teacher is overloaded with correspondence. The term for answering the question should not exceed 2-3 days.

To assess the quality of the organization of electronic consultation, we use the apparatus of mathematical theory of queuing. The process that takes place in the system "teacher - communication channel listener" can be considered as a single-channel queuing system with expectations.

Calculations performed according to experimental data showed that the average time $t_{\text {обсл }}$ spent by a teacher to respond to a letter from one student is about 20 minutes, ie $1 / 3$ of an hour. The intensity of the flow of applications $\lambda$ is (experimentally) 2 letters per hour. Using calculations, we obtain [32]:

- the average waiting time for a letter in the queue $t_{\text {cucm. }}$ is 1 hour;

- the capacity of the teacher $N_{n p}$ (average number of students to whom the teacher can assign an individual consultation) is equal to 20 students per day.

Thus, for the rational organization of the process of electronic consultation, according to the above calculations, the teacher is recommended:

- divide students into groups of 20 people;

- make a schedule for receiving correspondence;

- knowing the total number of students $\mathrm{N}$ and the capacity of the teacher $N_{n p}$, calculate the number of days (D) required for the consultation:

$$
D=N / N_{n p}
$$

- take into account the data obtained when compiling the consultation schedule.
In the course of research it was found that:

- when conducting group consultations in real time, the average number of students in the group should not exceed ten, so as not to create "queues";

- during the consultation (any type of connection) it is necessary to have an assistant - a consultant on technical issues.

At the final stage, after consultation, the teacher must:

- view and analyze the content of all issues;

- enter the most frequently asked questions in the personal database of the teacher;

- based on the results of the consultation, to correct the training material.

It should be noted that these operations are implicitly present in the traditional, face-to-face consultation. In the course of theoretical and experimental research it was found that when conducting electronic consultations, it is advisable to perform these steps in strict accordance with the established procedure; their obligatory fulfillment is a necessary condition for the success of the educational process [36-37].

\section{Conclusions}

Thus, the main advantages of the software systems developed and actively used at the KNAFU and responsible for assessing knowledge ("DIALOG", the universal system for the development and conducting of computer tests, MOODLE) are: automation of knowledge control processes for those learning; exclusion of "human factor", impartiality of evaluation; automatic fixing of test results; automatic statistical processing of test results and the formation of accounting records for personnel training. In the course of theoretical and experimental research to assess the quality of the organization of electronic consultation by using of the queueing theory mathematical apparatus it was found that when conducting electronic consultations, it is advisable to perform these steps in strict accordance with the established procedure; their obligatory fulfillment is a necessary condition for the success of the educational process.

For the rational organization of the process of electronic consultation, according to the above calculations, the teacher is recommended: divide students into groups of 20 people; make a schedule for receiving correspondence; calculate the number of days required for the consultation; take into account the data obtained when compiling the consultation schedule.

The existing on current time in KNAFU a educational-methodical base, hardware software and highly skilled scientifically-pedagogical composition of university, allow with a complete confidence to talk that educational establishment, from the point of view of automation and application in the educational process of modern information technologies fully prepare to 
integration in educational space of European Union and NATO countries, and the global problem related to the submission of the COVID-19 coronal infection, only accelerates the pace of development and implementation of new information technologies for the implementation of high-quality distance learning, both in Higher Military Educational Institutions of Ukraine, and Higher Educational Institutions all over the world in general.

\section{References}

1. The Order of the Ministry of Education and Science of Ukraine (2013), "Pro zatverdzhennya Polozhennya pro dystantsiyne navchannya № 466 vid 25.04.2013” [On approval of the Regulations on distance learning No. 466 dated 25.04.2013], available at: www. https://zakon.rada.gov.ua/laws/show/z0703-13\#Text (accessed 12 October 2021).

2. The Letter of the Ministry of Education and Science of Ukraine (2020), "Shchodo provedennya pidsumkovoho otsinyuvannya ta orhanizovanoho zavershennya 2019-2020 navchal'noho roku № 1/9-213 vid 16.04.2020" [Regarding the final assessment and organized completion of the 2019-2020 academic year No. 1/9-213 dated 16.04.2020], available at: https://mon.gov.ua/ua/npa/shodo-provedennya-pidsumkovogo-ocinyuvannya-ta-organizovanogo-zavershennya-2019-2020navchalnogo-roku (accessed 12 October 2021).

3. The Letter of the Ministry of Education and Science of Ukraine (2020), "Polozhennya shchodo orhanizatsiyi dystantsiynoho navchannya № 1/9-609 vid 02.11.2020" [The Regulation on the organization of distance learning No. 1/9-609 dated 02.11.2020], available at: https://mon.gov.ua/ua/npa/shodo-organizaciyi-distancijnogo-navchannya (accessed 12 October 2021).

4. The Ministry of Education and Science of Ukraine (2020), "Orghanizacija dystancijnogho navchannja $v$ shkoli: metodychni rekomendaciji" [Organization of distance learning in school: methodological recommendations], available at: https://mon.gov.ua/storage/app/media/zagalna\%20serednya/metodichni\%20recomendazii/2020/metodichni\%20recomendaziidustanciyna\%20osvita-2020.pdf (accessed 12 October 2021).

5. The Resolution of the Cabinet of Ministers of Ukraine (2020), "Pro zapobihannya poshyrennyu na terytoriyi Ukrayiny koronavirusu COVID-19 № 211 vid 11.03.2020" [On prevention of the spread of COVID-19 coronavirus on the territory of Ukraine №. 211 dated 11.03.2020], available at: https://frankfurt.mfa.gov.ua/npas/postanova-kmu-211-vid-11032020 (accessed 12 October 2021).

6. Kalachova, V., Misyura, O., Huriev, D., Zakirov, Z. and Kryzhanivskyi, I. (2021), Analysis of positive experience of effective application of distance learning technologies by higher education institutions of Ukraine during the coroniovirus epidemic COVID-19: Technical research and development: collective monograph, Primedia eLaunch LLC, Boston, USA, pp. 113-118.

7. Kalachova, V., Misyura, O., Huriev, D., Zakirov, Z. and Kryzhanivskyi, I. (2021), Analysis of successful examples of application of distance learning technologies by higher education institutions of Ukraine during the coroniovirus epidemic COVID-19, XXII International scientific and practical conference "Interaction of society and science: prospects and problems", April 20-23, London, pp. 533-540.

8. Mulyanti, B., Purnama, W., Pawinanto, R.E. (2020), Distance learning in vocational High Schools during the Covid-19 pandemic in West Java province, Indonesia, Indonesian Journal of Science and Technology, No. 5(2), pp. 271-282. available at: https://pesquisa.bvsalud.org/global-literature-on-novel-coronavirus-2019-ncov/resource/pt/covidwho-1235139.

9. Al-Balas, M., Al-Balas, H.I., Jaber, H.M. et all. (2020), Distance learning in clinical medical education amid COVID19 pandemic in Jordan: current situation, challenges, and perspectives, BMC Med. Educ., No. 20, pp. 341. https://doi.org/10.1186/s12909-020-02257-4.

10. Kalachova, V. and Popova, N. (2021), Information technologies on the way of solving the problem of the world educational crisis overcoming during the coronavirus infection pandemic Covid-19, IV International Scientific and Practical Conference “Recent Scientific Investigation”, December 11-12, Oslo, Norway, pp. 444-447.

11. The Official Site of Kharkiv National University of Radio Electronics. URL: https://nure.ua (accessed 12 October 2021).

12. The Ministry of Education and Science of Ukraine (2020), "Rekomendatsiyi shchodo orhanizatsiyi potochnoho, semestrovoho kontrolyu ta atestatsiyi zdobuvachiv fakhovoyi peredvyshchoyi ta vyshchoyi osvity iz zastosuvannyam dystantsiynykh tekhnolohiy navchannya № 1/9-249 vid 14.05.2020" [Recommendations for the organization of current, semester control and certification of applicants for professional higher and higher education with the use of distance learning technologies No. 1/9-249 dated 14.05.2020], available at: https://osvita.ua/legislation/Vishya_osvita/73574 (accessed 12 October 2021).

13. Cloud technologies in education. Advantages G Suite and Office 365. URL: https://sites.google.com/view/cloudinedu (accessed 12 October 2021)

14. The Official Site of National Technical University "Kharkiv Polytechnic Institute", URL: https://www.kpi.kharkov.ua (accessed 12 October 2021).

15. "Zoom - zruchnyj dodatok dlja videokonferencij: jak pracjuje i de zavantazhyty proghramu" [Zoom - a convenient application for video conferencing: how it works and where to download the program], URL: https://senior.ua/news/zoom-zruchniy-dodatok-dlya-vdeokonferency-yak-pracyu--de-zavantazhiti-programu (accessed 12 October 2021).

16. TechExpert (2021), Microsoft 365 for Education. URL: https://techexpert.ua/it-products/microsoft-365-education (accessed 12 October 2021)

17. The Official Site of Ivan Kozhedub Kharkiv National Air Force University. URL: http://www.hups.mil.gov.ua/ (accessed 12 October 2021).

18. Romanenko, I.O., Sumtsov, D.V., Kalachova, V.V. and Suk, O.P. (2010), "Dystantsiyne navchannya. Osnovy, kontseptsiyi, perspektyvy (hryf nadano MON - lyst №1/II-10437 vid 22.12.2009 r.)" [Distance learning. Fundamentals, concepts, perspectives (stamp provided by the Ministry of Education and Science letter №1 / II-10437 dated 22.12.2009)], NTU "KhPI", Kharkiv, $276 \mathrm{p}$.

19. Kalachova, V. (2021), Ways to apply of distance learning technologies by Kharkiv National University of the Air Force 
during the coroniovirus epidemic Covid-19, XI International Scientific and Practical Conference "Theoretical approaches of Fundamental Sciences. Theory, Practice and Prospects”, Geneva, Switzerland, April 26-28, 2021, pp. 216-219.

20. Kalachova, V. and Misyura, O. (2019), Automation of the Educational Process in Ukraine Higher Military Education Institutions, III International Scientific and Technical Conference "Computer and Information Systems and Technologies", April 23-24, KNURE, Kharkiv - Riga - Kyiv - Lviv - Baku, pp. 58-60.

21. Moore, J., Dickson-Deane, C., Galyen, K. (2011), E-learning, online learning, and distance learning environments: are they the same? Internet High. Educ., No. 14(2), pp. 129-135. https://doi.org/10.1016/J.IHEDUC.2010.10.001.

22. Kalachova, V.V. and Kolmykov, M.M. (2012), "Intelektual'ni pidsystemy testuvannya znan' dlya dystantsiynoho navchannya viys'kovykh fakhivtsiv" [Intelligent subsystems of knowledge testing for distance learning of military specialists], VIII Scientific Conference HAFU "The newest technologies - to defend the airspace", April 13-14, KAFU, Kharkiv, pp. 132-133.

23. Romanenko, I.O., Dudenko, S.V., Babenko, O.P. and Kalachova, V.V. (2013), "Imovirnisno-informatsiynyy pidkhid na shlyakhu vyrishennya zadachi otsinyuvannya rivnya boyovoyi vyuchky orhaniv upravlinnya ZS Ukrayiny" [The probabilisticinformational approach on the way of solving the task of assessment the level of combat training of the governing bodies of the Armed Forces of Ukraine], Scientific works of Kharkiv Air Force University, No. 1(34), KAFU, Kharkiv, pp. 36-39.

24. Ruban, I.V., Tkachuk, S.S., Kalachova, V.V., Nosik, A.M. and Tkachov, A.M. (2013), "Shlyakhy realizatsiyi informatsiynoyi tekhnolohiyi otsinyuvannya boyovoyi vyuchky orhaniv viys'kovoho upravlinnya ZSU" [The ways of realization of information technology of assessment of combat training of the military governing bodies of the Armed Forces of Ukraine], Science i Technology of the Air Force of Ukraine, No. 4(13), pp. 14-17.

25. Smelyakov, K.S., Alekseev, S.V., Romanenko, I.O., Babenko, O.P., Ruban, I.V. and Kalachova, V.V. (2013), "Metodyka intehral'noyi otsinky stupenya atestovanosti ta strukturnyy alhorytm testuvannya prohramnoho zabezpechennya" [The method of integral assessment of the degree of attestation and the structural algorithm of software testing], Scientific works of Kharkiv National Air Force University, No. 2(35), pp. 120-126.

26. O'doherty, D., Dromey, M., Lougheed, J., Hannigan, A., Last, J. and McGrath, D. (2018), Barriers and solutions to online learning in medical education - an integrative review, BMC Med. Educ., No. 18, pp. 130-145. https://doi.org/10.1186/s12909-018-1240-0.

27. Kalachova, V.V., Misyura, O.M., Tretyak, V.F., Kuzhel, I.E., Trublin, O.A., Shigimaga, N.V. and Shkurupiy, S.S. (2018), "Ovolodinnya navychkamy roboty z prohramnym kompleksom "Kaskad" - yak shlyakh do optymizatsiyi roboty VVNZ ta yevrointehratsiyi vyshchoyi osvity Ukrayiny" [Mastering the skills of working with the software complex "Cascade" - as a way to optimize the work of universities and European integration of higher education in Ukraine], Educational and methodical works of KNAFU, No. 1(147), pp. 38-47.

28. Misyura, O.M., Pichugin, M.F., Alekseev, S.V., Kalachova, V.V. and Trublin, O.A. (2017), "Analiz osoblyvostey rozrobky, ekspluatatsiyi ta podal'shoho rozvytku kompleksu prohram avtomatyzovanoyi systemy konstruyuvannya navchal'noho rozkladu "Kaskad" [Analysis of the peculiarities of development, operation and further development of the complex of programs of the automated system of designing the educational schedule "Cascade"], Information Processing Systems, No. 4(150), pp. 193-198. https://doi.org/10.30748/soi.2017.150.40.

29. Tyshchenko, M.G., Misyura, O.M., Tretyak, V.F., Kalachova, V.V. and Trublin, O.A. (2018), “Osoblyvosti rozrobky dyzaynu interfeysu kompleksu prohram avtomatyzovanoyi systemy konstruyuvannya rozkladu zanyat' $\mathrm{v}$ Kharkivs'komu natsional'nomu universyteti Povitryanykh Syl "Kaskad" [Peculiarities of interface design development of the complex of programs of the automated system of designing the schedule of classes at the Kharkiv National University of the Air Force "Cascade"], Scientific works of Kharkiv National Air Force University, No. 3(57), pp. $144-151$. https://doi.org/10.30748/zhups.2018.57.22.

30. Kalachova, V.V., Dzeverin, I.G., Kruk, B.M., Zakirov, Z.Z. and Tretyak, D.V. (2020), "Kompleks prohram avtomatyzovanoyi systemy konstruyuvannya rozkladu zanyat' "Kaskad" [The Complex of designing the schedule of classes "Cascade"], International Scientific and Practical Conference Scientific community: Interdisciplinary research, September 2628, Hamburg, German, pp. 75-82.

31. Kalachova, V. and Shcherbinin, S. (2021), Example of the Kharkiv National University of the Air Force on the issue of ways to overcome the educational crisis during the pandemic of coronavirus infection COVID-19, XVI International Scientific and Practical Conference "Actual problems of science and practice", May 31 - June 02, Stockholm, Sweden, pp. 164-167.

32. Kalachova, V., Tretyak, V., Misyura, O. (2006-2008), "Zvit pro NDR. Rozrobka spetsializovanoho informatsiynoosvitn'oho seredovyshcha dlya dystantsiynoho navchannya z boyovoyi pidhotovky chastyn ta pidrozdiliv Povitryanykh Syl Zbroynykh Syl Ukrayiny (shyfr "Dialoh") -3 chastyny" [SRW report. Development of a specialized information and educational environment for distance learning in combat training of units and subdivisions of the Air Force of the Armed Forces of Ukraine (code "Dialogue"), 3 Parts], KNAFU, Kharkiv.

33. Kalachova, V. and Khvorost, O. (2021), Features of determination of groups of users of DLS in supreme military educational institutions of the Armed Forces of Ukraine during the pandemic of coronavirus infection COVID-19, IV International Scientific and Practical Conference "Global and regional aspects of sustainable development", July 06-08, Copenhagen, Denmark, pp. 153-158.

34. Anderson, T. and Dron, J. (2011), Three generations of distance education pedagogy, Int Rev Res Open Distributed Learning, No. 12(3), pp. 80-97. https://doi.org/10.19173/irrodl.v12i3.890.

35. Kalachova, V. (2021), Ways of solving the problem of overcoming the world educational crisis from Kharkiv National Air Force University, I International Scientific and Practical Conference "Multidisciplinary academic research", Amsterdam, Netherlands, September 20-22, pp. 81-84.

36. Tretiak, V. and Kolomiytcev, O. (2021), "Suchasnyy stan provedennya naukovykh doslidzhen' u IT-tekhnolohiyakh, haluzyakh elektroniky, inzheneriyi, nanotekhnolohiyakh ta transportnifiy sferi: kolektyvna monohrafiya" [The modern state of research in IT-technologies, electronics, engineering, nanotechnology and transport: a collective monograph], European Scientific Platform, Vinnytsia, 160 p.

37. Ageycheva, A. and Bukhkalo, S. (2013), Some features of the development of distance education in Sweden, Bulletin of NTU “KhPI”, No. 55, pp. 162-168. 


\section{Список літератури}

1. Про затвердження Положення про дистанційне навчання : Наказ Міністерства освіти і науки України від 25 квітня 2013 р. № 466. URL: https://zakon.rada.gov.ua/laws/show/z0703-13\#Text (дата звернення: 12.10.2021).

2. Щодо проведення підсумкового оцінювання та організованого завершення 2019-2020 навчального року : Лист Міністерства освіти і науки України від 16 квітня 2020 р. №1/9-213. URL: https://mon.gov.ua/ua/npa/shodo-provedennyapidsumkovogo-ocinyuvannya-ta-organizovanogo-zavershennya-2019-2020-navchalnogo-roku (дата звернення: 12.10.2021).

3. Положення щодо організації дистанційного навчання : Лист Міністерства освіти і науки України від 02 листопада 2020 р. № 1/9-609. URL: https://mon.gov.ua/ua/npa/shodo-organizaciyi-distancijnogo-navchannya (дата звернення: 12.10.2021).

4. Організація дистанційного навчання в школі : методичні рекомендації MOH України : веб-сайт. URL: https://mon.gov.ua/storage/app/media/zagalna\%20serednya/metodichni\%20recomendazii/2020/metodichni\%20recomendaziidustanciyna\%20osvita-2020.pdf (дата звернення: 12.10.2021).

5. Про запобігання поширенню на території України коронавірусу COVID-19 : Рішення Кабінету Міністрів України від 11 березня 2020p. № 211. URL: https://frankfurt.mfa.gov.ua/npas/postanova-kmu-211-vid-11032020 (дата звернення: 12.10.2021).

6. Analysis of positive experience of effective application of distance learning technologies by higher education institutions of Ukraine during the coroniovirus epidemic COVID-19 / Kalachova V. et all. Technical research and development: monograph. USA: Primedia eLaunch LLC, 2021. P. 113-118.

7. Kalachova V., Misyura O., Huriev D., Zakirov Z., Kryzhanivskyi I. Analysis of successful examples of application of distance learning technologies by higher education institutions of Ukraine during the coroniovirus epidemic COVID- 19. Interaction of society and science: prospects and problems : proceedings of XXII International scientific and practical conference, London, 20-23 april 2021, London, 2021. P. 533-540.

8. Mulyanti B., Purnama W., Pawinanto R. E. Distance learning in vocational High Schools during the Covid-19 pandemic in West Java province, Indonesia. Indonesian Journal of Science and Technology. 2020. No. 5(2). P. 271-282. https://pesquisa.bvsalud.org/global-literature-on-novel-coronavirus-2019-ncov/resource/pt/covidwho-1235139.

9. Al-Balas M., Al-Balas H.I., Jaber H.M. et all. Distance learning in clinical medical education amid COVID-19 pandemic in Jordan: current situation, challenges, and perspectives. BMC Med Educ. 2020. No. 20. P. 341. https://doi.org/10.1186/s12909-020-02257-4.

10. Kalachova V., Popova N. Information technologies on the way of solving the problem of the world educational crisis overcoming during the coronavirus infection pandemic Covid-19. Recent Scientific Investigation : proceedings IV International Scientific and Practical Conference, Oslo, 11-12 december 2021. Oslo, Norway, 2021. P. 179-183.

11. Харківський національний університет радіоелектроніки : веб-сайт. URL: https://nure.ua (дата звернення: 12.10.2021).

12. Рекомендації щодо організації поточного, семестрового контролю та атестації здобувачів фахової передвищої та вищої освіти із застосуванням дистанційних технологій навчання : Лист Міністерства освіти і науки України від 14 травня 2020 р. № 1/9-249. URL: https://osvita.ua/legislation/Vishya_osvita/73574/ (дата звернення: 12.10.2021).

13. Переваги G Suite i Office 365. Хмарні технології в освіті : веб-сайт. URL: https://sites.google.com/view/cloudinedu (дата звернення: 12.10.2021).

14. Національний технічний університет "Харківський політехнічний інститут" : веб-сайт. URL: https://www.kpi.kharkov.ua (дата звернення: 12.10.2021).

15. Zoom - зручний додаток для відеоконференцій: як працює і де завантажити програму : веб-сайт. URL: https://senior.ua/news/zoom--zruchniy-dodatok-dlya-vdeokonferency-yak-pracyu--de-zavantazhiti-programu (дата звернення: 12.10.2021).

16. Microsoft 365 для Освіти. TechExpert : веб-сайт. URL: https://techexpert.ua/it-products/microsoft-365-education (дата звернення: 12.10.2021).

17. Харківський національний університет Повітряних Сил імені Івана Кожедуба : веб-сайт. URL: http://www.hups.mil.gov.ua/ (дата звернення: 12.10.2021).

18. Дистанційне навчання. Основи, концепції, перспективи. (гриф надано МОН лист №1/II-10437 від 22.12.2009р.): навч. посіб. / Романенко І. О., Сумцов Д. В., Калачова В. В., Сук О. П. Харків : НТУ““ХПІ, 2010. 276 с.

19. Калачова В. Ways to apply of distance learning technologies by Kharkiv National University of the Air Force during the coroniovirus epidemic Covid-19. Theoretical approaches of Fundamental Sciences. Theory, Practice and Prospects : proceedings of XI International Scientific and Practical Conference, Geneva, 26-28 April 2021. Geneva, Switzerland, 2021. P. 216-219.

20. Kalachova V. V., Misyura O. M. Automation of the Educational Process in Ukraine Higher Military Education Institutions. Комп'ютерні та інформаційні системи і технологї : зб. тез доп. III міжнарод. наук.-техн. конф., Харків Рига - Київ - Львів - Баку, 23-24 квіт. 2019 р. Харків, 2019. С. 58-60.

21. Moore J., Dickson-Deane C., Galyen K. E-learning, online learning, and distance learning environments: are they the same? Internet High. Educ. 2011. No.14(2). P. 129-135. https://doi.org/10.1016/J.IHEDUC.2010.10.001.

22. Калачова В. В., Колмиков М. М. Інтелектуальні підсистеми тестування знань для дистанційного навчання військових фахівців. Новітні технологї - для захисту повітряного простору : зб. тез доп. VIII наук. конф. Харківського університету Повітряних Сил ім. Івана Кожедуба, м. Харків, 13-14 квіт. 2012 р. Харків, 2012. С. 132-133.

23. Романенко І. О., Дуденко С. В., Бабенко О. П., Калачова В. В. Імовірнісно-інформаційний підхід на шляху вирішення задачі оцінювання рівня бойової виучки органів управління ЗС України. Збірник наукових праць Харківського університету Повітряних Сил. 2013. № 1(34). С. 36-39.

24. Рубан І. В., Ткачук С. С., Калачова В. В., Носик А. М., Ткачов А. М. Шляхи реалізації інформаційної технології оцінювання бойової виучки органів військового управління ЗСУ. Наука і техніка Повітряних Сил Збройних Сил Украӥни. 2013. № 4(13). С. 14-17. 
25. Смеляков К. С., Алексєєв С. В., Романенко І. О., Бабенко О. П., Рубан І. В., Калачова В. В. Методика інтегральної оцінки ступеня атестованості та структурний алгоритм тестування програмного забезпечення. Збірник наукових праць Харківського університету Повітряних Сил. 2013. № 2(35). С. 120-126.

26. O'doherty D., Dromey M., Lougheed J., Hannigan A., Last J., McGrath D. Barriers and solutions to online learning in medical education - an integrative review. BMC Med. Educ. 2018. No. 18. P. 130-145. https://doi.org/10.1186/s12909-018-1240-0.

27. Калачова В. В., Місюра О. М., Третяк В. Ф., Кужель І. Є., Трублін О. А., Шигімага Н. В., Шкурупій С. С. Оволодіння навичками роботи 3 програмним комплексом “Каскад” - як шлях до оптимізації роботи ВВНЗ та євроінтеграції вищої освіти України. Навчально-методичний збірник ХНУПС. 2018. № 1(147). С. 38-47.

28. Місюра О. М., Пічугін М.Ф., Алексєєв С.В., Калачова В.В., Трублін О.А. Аналіз особливостей розробки, експлуатації та подальшого розвитку комплексу програм автоматизованої системи конструювання навчального розкладу “Каскад”. Системи обробки інформаџіï. 2017. № 4(150). C. 193-198. https://doi.org/10.30748/soi.2017.150.40.

29. Тищенко М. Г., Місюра О. М., Третяк В. Ф., Калачова В. В., Трублін О. А. Особливості розробки дизайну інтерфейсу комплексу програм автоматизованої системи конструювання розкладу занять в Харківському національному університеті Повітряних Сил “Каскад”. Збірник наукових праць Харківського наџіонального університету Повітряних Сил. 2018. № 3(57). С. 144-151. https://doi.org/10.30748/zhups.2018.57.22.

30. Калачова В. В., Дзеверін І. Г., Крук Б. М., Закіров 3. З., Третяк В. Ф. Комплекс програм автоматизованої системи конструювання розкладу занять “Каскад”. Interdisciplinary research : зб. тез доп. International Scientific and Practical Conference Scientific community, Гамбург, 26-28 вересня 2020. Гамбург, Німеччина, 2020. C. 75-82.

31. Kalachova V., Shcherbinin S. Example of the Kharkiv National University of the Air Force on the issue of ways to overcome the educational crisis during the pandemic of coronavirus infection COVID-19. Actual problems of science and practice : conference paper XVI International Scientific and Practical Conference, Stockholm, 31 May - 02 June 2021. Stockholm, Sweden, 2021. P. 164-167.

32. Місюра О. М., Третяк В. Ф., Калачова В. В. Звіт про НДР : Розробка спеціалізованого інформаційно-освітнього середовища для дистанційного навчання з бойової підготовки частин та підрозділів Повітряних Сил Збройних Сил України (шифр “Діалог”). МОУ, ХУПС. № ДР 010Ш000601; Харків, 2006-2008. в 3 Ч.

33. Kalachova V., Khvorost O. Features of determination of groups of users of DLS in supreme military educational institutions of the Armed Forces of Ukraine during the pandemic of coronavirus infection COVID-19. Global and regional aspects of sustainable development. IV International Scientific and Practical Conference: conference paper. Copenhagen, Denmark, 06-08 Luly, 2021. Copenhagen, Denmark, 2021. P. 153-158.

34. Anderson T., Dron J. Three generations of distance education pedagogy. Int Rev Res Open Distributed Learning. 2011. No. 12(3). P. 80-97. https://doi.org/10.19173/irrodl.v12i3.890.

35. Калачова В. В. Ways of solving the problem of overcoming the world educational crisis from Kharkiv National Air Force University. Multidisciplinary academic research : conference paper of I International Scientific and Practical Conference, Amsterdam, 20-22 September 2021. Amsterdam, Netherlands, 2021. P. 81-84.

36. Третяк В., Коломийцев О. Сучасний стан проведення наукових досліджень у IT-технологіях, галузях електроніки, інженерії, нанотехнологіях та транспортніфій сфері. Вінниця : Європейська наукова платформа, 2021. $160 \mathrm{c}$.

37. Агейчева А. О., Бухкало С. І. Деякі особливості розвитку дистанційної освіти Швеції. Вісник НТУ “ХПГ”. 2013. Вип. 55. С. 162-168.

\section{Відомості про авторів:}

\section{Калачова Віроніка Валеріївна} кандидат технічних наук доцент старший науковий співробітник старший науковий співробітник

Харківського національного університету

Повітряних Сил ім. І. Кожедуба,

Харків, Україна

https://orcid.org/0000-0003-3477-0858

\section{Оваід Сальман Рашід}

кандидат технічних наук

коледж університету Al Maaref,

Республіка Ірак

https://orcid.org/0000-0002-1189-9707

\section{Місюра Олег Миколайович}

кандидат технічних наук старший науковий співробітник заступник начальника наукового центру

Харківського національного університету

Повітряних Сил ім. І. Кожедуба,

Харків, Україна

https://orcid.org/0000-0002-3025-3477

\section{Information about the authors:}

\author{
Vironika Kalachova \\ $\mathrm{PhD}$ in Engineering \\ Associate Professor Senior Researcher \\ Senior Researcher \\ of Ivan Kozhedub Kharkiv National \\ Air Force University, \\ Kharkiv, Ukraine \\ https://orcid.org/0000-0003-3477-0858
}

\section{Owaid Salman}

$\mathrm{PhD}$ in Engineering

of Al Maaref University College,

Republic of Iraq

https://orcid.org/0000-0002-1189-9707

\section{Oleg Misiura}

$\mathrm{PhD}$ in Engineering Senior Researcher Deputy Head of the Research Center of Ivan Kozhedub Kharkiv National

Air Force University,

Kharkiv, Ukraine

https://orcid.org/0000-0002-3025-3477 
Третяк В'ячеслав Федорович

кандидат технічних наук

старший науковий співробітник доцент

начальник науково-дослідної лабораторії

Харківського національного університету

Повітряних Сил ім. І. Кожедуба,

Харків, Україна

https://orcid.org/0000-0003-2599-8834

\section{Сафошкіна Людмила Володимирівна}

кандидат технічних наук

старший науковий співробітник науково-дослідного центру

Національної академії Національної гвардії України,

Харків, Україна

https://orcid.org/0000-0001-6336-8919

\section{Гончар Роман Олександрович}

кандидат військових наук старший дослідник

старший науковий співробітник

науково-дослідного центру

Національної академії Національної гвардії України,

Харків, Україна

https://orcid.org/0000-0003-0948-5422
Viacheslav Tretiak

$\mathrm{PhD}$ in Engineering Senior Researcher

Associate Professor

Head of Scientific Research Laboratory

of Ivan Kozhedub Kharkiv National

Air Force University,

Kharkiv, Ukraine

https://orcid.org/0000-0003-2599-8834

\section{Lyudmila Safoshkina}

$\mathrm{PhD}$ in Engineering

Senior Researcher of the Scientific Center

of National Academy of National Guard of Ukraine,

Kharkiv, Ukraine

https://orcid.org/0000-0001-6336-8919

\section{Roman Honchar}

PhD in Military Science Senior Researcher

Senior Researcher

of the Scientific Center

of National Academy of National Guard of Ukraine,

Kharkiv, Ukraine

https://orcid.org/0000-0003-0948-5422

\title{
ШЛЯХИ ОРГАНІЗАЦІЇ ДИСТАНЦІЙНОГО НАВЧАННЯ У ВИЩИХ ВІЙСЬКОВИХ НАВЧАЛЬНИХ ЗАКЛАДАХ УКРАЇНИ ТА СВІТУ ПІД ЧАС ПОДОЛАННЯ ПАНДЕМІЇ КОРОНОВІРУСНОЇ ІНФЕКЦІЇ СОVID-19
}

\author{
В.В. Калачова, Оваід Сальман Рашід, О.М. Місюра, В.Ф. Третяк, Л.В. Сафошкіна, Р.О. Гончар
}

Глобальна інформатизація сучасного суспільства, розвиток телекомунікаиійних, комп'ютерних та інформаційних технологій - з одного боку і потужні виклики до всього людства у вигляді епідемій (короновірусна інфекція COVID-19, пташиний грип, різні форми пневмоній та гепатитів), природних та техногенних катастроф, військових та політичних конфліктів - з другого, обумовлюють суттєві зміни пріоритетних форм здійснення освітнього прочесу, $i$ дистанційне навчання (ДН) в иих умовах стає єдиним можливим варіантом надання якісних освітніх послуг при мінімальних фінансових витратах на його організацію. Придбаний під час карантину, спричиненого спалахом короновірусної інфекиії COVID-19, позитивний досвід ефективної організаиії освітнього проиесу із застосуванням технологій ДН провідними ВНЗ (ВВНЗ) України може стати у нагоді для фахівиів з питань розробки та застосування механізмів навчання на відстані з інших чивільних і військових навчальних закладів Украйни та світу. Враховуючи той факт, щео ДН є однією з форм безперервної освіти, щэо покликане реалізувати права людини на освіту та в основу якого покладена иілеспрямована й контрольована інтенсивна самостійна робота користувача освітніх послуг, який може навчатися у зручному для себе місиі, за індивідуальним розкладом, маючи при собі комплект спеціальних засобів навчання і погоджену можливість контакту з викладачем, фахівиям ВНЗ з питань організачї ДН, особливо, як у випадку з карантином, коли ДН - є вимушеним кроком, потрібно зробити ие навчання максимально комфортним, інновачійним, наукоємним та надсучасним, щоб мотивувати тих очних, щуо навчаються, хто незацікавлений в переходi до дистанційної форми навчання. Тому, МОН України, розробляючи навесні 2020 року Рекомендації шфодо можливих варіантів дистанційної комунікації учасників освітнього процесу в період карантину, намагалося застосувати найбільш брендові та популярні серед молоді засоби комунікаиії, вбудовані до систем управління навчанням (LMS); електронну пошту; месенджери; відеоконферениії; форуми; чати тощо. В свою чергу, широкі можливості сучасних інформаційних технологій щодо створення імітаційних моделей об'єктів і проиесів (flash-анімація, 3-D моделі та інші), дозволяють візуалізувати інформачію і зробити контент дистанційного курсу максимально зрозумілим та иікавим для вивчення, навіть, первісно незачікавленим в цьому навчанні користувачам.

Ключові слова: дистаниійне навчання, інформаційно-освітне середовище, система дистанційного навчання, інформаційна технологія, система управління навчанням, месенджер, відеоконференція, форум, чат.

\section{ПУТИ ОРГАНИЗАЦИИ ДИСТАНЦИОННОГО ОБУЧЕНИЯ В ВЫСШИХ ВОЕННЫХ УЧЕБНЫХ ЗАВЕДЕНИЯХ УКРАИНЫ И МИРА ВО ВРЕМЯ ПРЕОДОЛЕНИЯ ПАНДЕМИИ КОРОНОВИРУСНОЙ ИНФЕКЦИИ СОVID-19}

В.В. Калачева, Оваид Сальман Рашид, О.Н. Мисюра, В.Ф. Третьяк, Л.В. Сафошкина, Р.А. Гончар

Глобальная информатизачия современного общества, развитие телекоммуникачионных, компьютерных и информачионных технологий - c одной стороны и мочные вызовы ко всему человечеству в виде эпидемий (короновирусная инфекиия COVID-19, птичий грипn, разные формы пневмоний и гепатитов), природных и техногенных катастроф, военных и политических конфликтов - с другой, обуславливают существенные изменения приоритетных форм осуществления учебного проиесса, и дистанционное обучение (ДО) в этих условиях становится единственным возможным вариантом предоставления качественных образовательных услуг при минимальных финансовых расходах на его организачию.

Ключевые слова: дистанционное обучение, информачионно-ообразовательная среда, система дистанционного обучения, информационная технология, система управления обучением, мессенджер, видеоконферениия, форум, чат. 